U.S. Department of Commerce Technology Administration

National Institute of Standards and Technology Gaithersburg, Maryland 20899

\title{
Economic Analysis of Residential Fire Sprinkler Systems
}

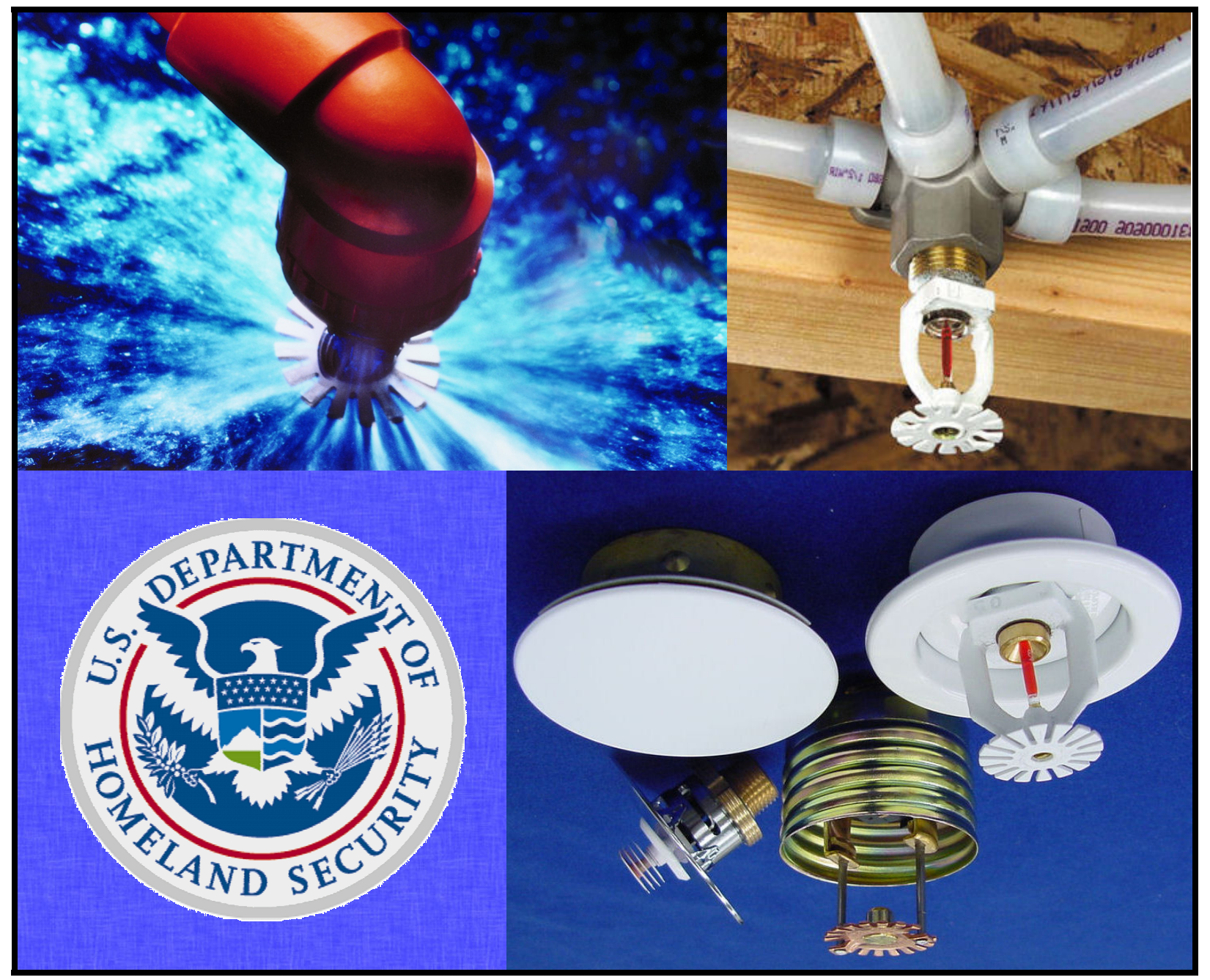


The fire sprinkler images on the cover, clockwise from top left, courtesy of Noveon, Inc., Uponor Wirsbo, and the United States Fire Administration. 


\section{Economic Analysis of Residential Fire Sprinkler Systems}

Hayden Brown

Funded by:

United States Fire Administration (USFA)

Emmitsburg, MD 21727

December 2005
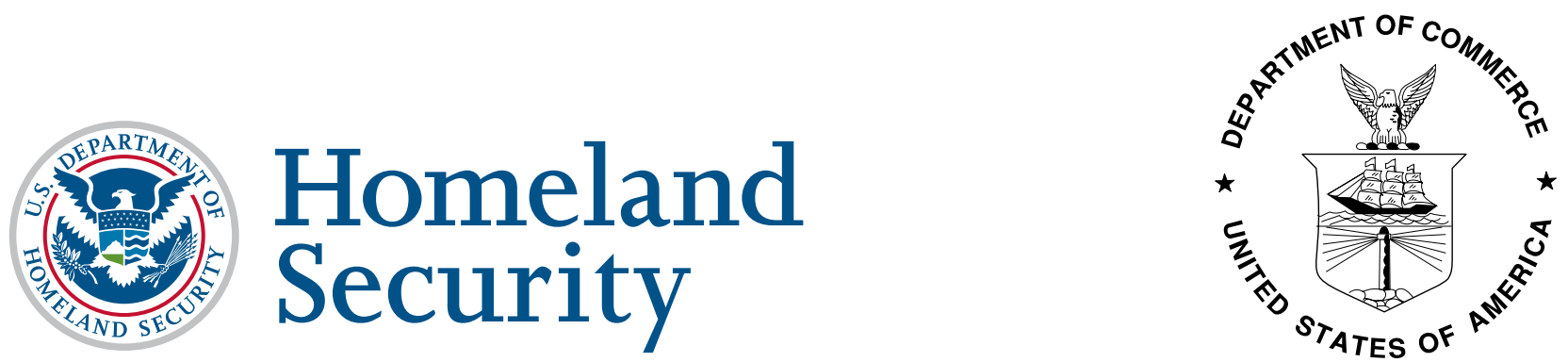

Department of Homeland Security

Michael Chertoff, Secretary

U.S. Fire Administration

R. David Paulison, Administrator
U.S. Department of Commerce Carlos M. Gutierrez, Secretary Technology Administration Dr. William A. Jeffrey, Acting Under Secretary for Technology National Institute of Standards and Technology Dr. William A. Jeffrey, Director 



\begin{abstract}
This report designs and applies a comparative life-cycle cost analysis to multipurpose network and stand-alone fire sprinkler systems designed in compliance with NFPA 13D. The life-cycle costs of the systems are studied in each of three NIST-designed prototypical house floorplans: a $3338 \mathrm{ft}^{2}$ $\left(310 \mathrm{~m}^{2}\right)$ two-story colonial with basement, a $2257 \mathrm{ft}^{2}\left(210 \mathrm{~m}^{2}\right)$ three-story townhouse, and a $1171 \mathrm{ft}^{2}$ $\left(109 \mathrm{~m}^{2}\right)$ single-story ranch.

The economic analysis follows the standard method in ASTM E917-02, and includes those elements of life-cycle cost that are unique to each system, such as design, material, installation and inspection costs. System plans, a comprehensive list of required components, and material costs were obtained from manufacturers and sprinkler system installers. NIST economists obtained data on a multipurpose network design and three stand-alone designs from manufacturers and sprinkler system installers. To these material cost data were added estimates of installation cost and design cost. In addition to the economic analysis of the sprinkler system designs, this report documents the collection and development of the cost data.
\end{abstract}

The comparative analysis is applied to the cost data to determine which of the proposed systems analyzed in this report has the lowest estimated life-cycle cost. Estimated cost results for all systems are within a close range, and are most sensitive to the decision to incorporate a backflow preventer. Both the cost data in this report and the cost-effectiveness analysis are intended to support a followon benefit-cost study by NIST on residential sprinkler systems.

Key Words: building economics, cost analysis, cost-effective decision, economic analysis, fire sprinkler, life-cycle cost 



\section{Preface}

This study was conducted by the Office of Applied Economics in the Building and Fire Research Laboratory at the National Institute of Standards and Technology. The study compares life-cycle costs of multipurpose network and stand-alone residential fire sprinkler systems, using design and cost data presented in the report. The basic systems contained in this report are all assumed to meet the NFPA 13D standard, with no system encountering a higher failure rate or requiring more maintenance or service.

Floorplans of prototypical houses, shown in Appendix A, were developed to form a physical basis for cost estimations. The sprinkler system designs reproduced in Appendix B and C are courtesy of the designer noted and should not be construed as endorsed or recommended by NIST.

This report was developed with funding from the U. S. Fire Administration (USFA). The USFA encourages the increased use of residential sprinkler systems as a means of reducing the loss of life and property in residential fires.

Disclaimer: Certain trade names or company products are mentioned in the text to specify adequately the experimental procedure and equipment used. In no case does such identification imply recommendation or endorsement by the National Institute of Standards and Technology, nor does it imply that the equipment is the best available for the purpose.

Disclaimer Regarding Non-metric Units: The policy of the National Institute of Standards and Technology is to use metric units in all its published materials. All of the sprinkler system design data such as room dimensions and pipe lengths were obtained in customary units. Because this report is intended for U.S. builders and contractors who use customary units, it is more practical and less confusing to use customary units rather than metric units within tables. Throughout the text of this report, measurement values stated in customary units are listed first, followed by the corresponding values in metric units within parentheses. 



\section{Acknowledgements}

Thanks are due to Dan Madrzykowski and Doug Walton of the Fire Research Division of the Building and Fire Research Laboratory. Dan Madrzykowski initiated this project and facilitated the collection of cost data, and Doug Walton designed the house plans. Thanks are also given to Harold Marshall, Robert Chapman and Linde Fuller of the Office of Applied Economics for their many helpful comments and suggestions on the cost parameters and on the analysis methodology. Special appreciation is extended to OAE staff members Julie Wean for her research, Tessa Beavers for her work with tables of data, and Douglas Thomas for assistance with the cover photographs.

Special thanks are given to Mr. Larry Maruskin of the U.S. Fire Administration for supporting this project; and Fred Benn, of Advanced Automatic Sprinkler, Inc.; Jonathan Bittenbender of REHAU

Inc.; Phillip Brown, of the American Fire Sprinkler Association, Russ Fleming of the National Fire Sprinkler Association; Gary Johnson of Noveon, Inc.; Alan Larson, of Uponor Wirsbo, Inc.; Eric Price of Engineered Fire Systems, Inc.; Steve Rians, of Standard Automatic Fire Enterprises, Inc.; and Pete Schwab of Wayne Automatic Fire Sprinkler for technical assistance without which this report could not have been written. 



\section{Table of Contents}

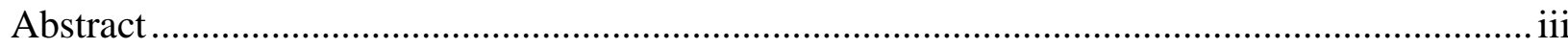

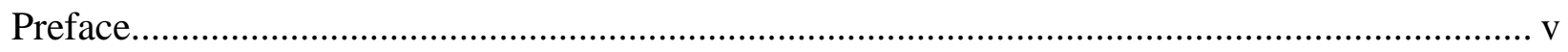

Acknowledgements .................................................................................................................. vii

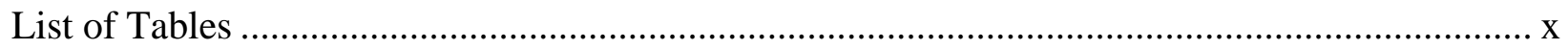

List of Figures .................................................................................................................

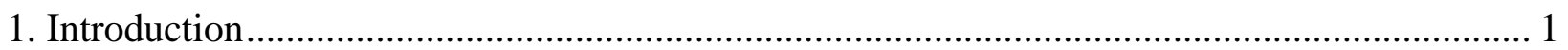

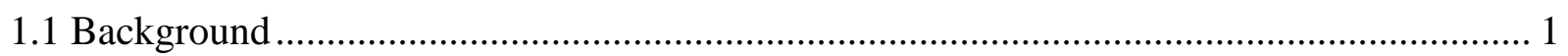

1.2 Purpose and Scope of Approach ...................................................................................... 1

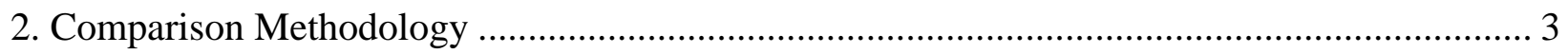

2.1 Introduction to Life-Cycle Cost (LCC) Method ................................................................... 3

2.2 Sprinkler Alternatives .................................................................................................. 5

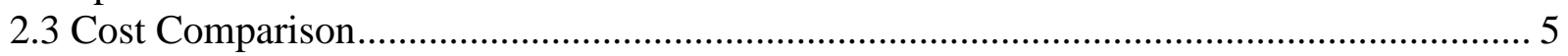

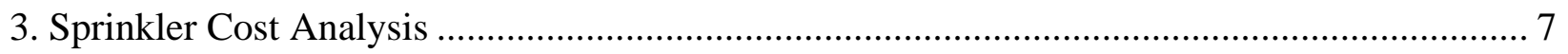

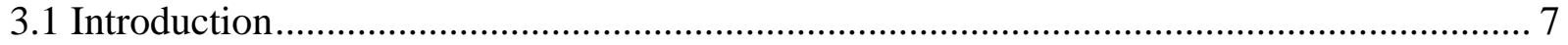

3.2 Purchase and Installation Cost Estimates ……………........................................................ 7

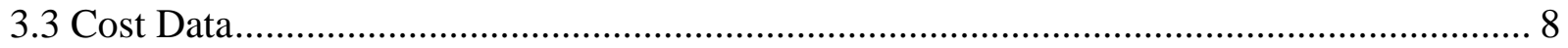

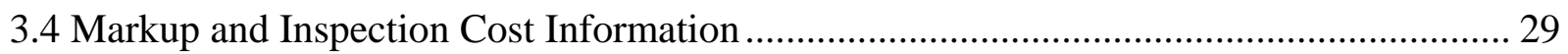

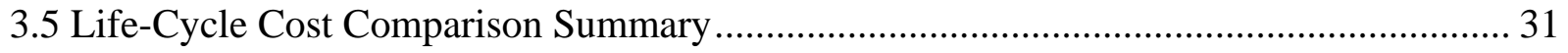

4. Summary and Suggestions for Future Research ………........................................................ 33

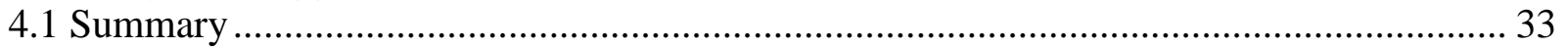

4.2 Suggestions for Future Research ..................................................................................... 33

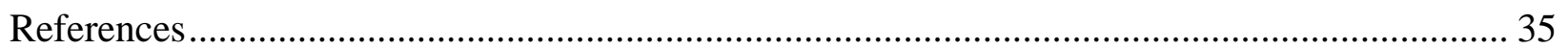

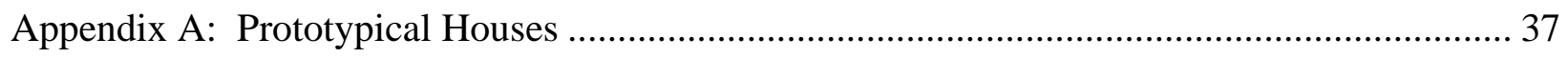

Appendix B: Stand-Alone Fire Sprinkler Installation Plan ............................................................. 43

Appendix C: Multipurpose Network Sprinkler Installation Plan ................................................ 49 


\section{List of Tables}

Table 2-1. List of Cost Estimation Tables by Fire Sprinkler System and House Type................ 5

Table 3-1. Cost Summary: Alternative A (Multipurpose Network System Using PEX) for a

New $3338 \mathrm{ft}^{2}\left(310 \mathrm{~m}^{2}\right)$ Single Family Colonial House.................................................... 11

Table 3-2. Cost Summary: Alternative A (Multipurpose Network System Using PEX) for a

New $2257 \mathrm{ft}^{2}\left(210 \mathrm{~m}^{2}\right)$ Single Family Townhouse ...................................................... 12

Table 3-3. Cost Summary: Alternative A (Multipurpose Network System Using PEX) for a New $1171 \mathrm{ft}^{2}\left(109 \mathrm{~m}^{2}\right)$ Single Family Ranch House .................................................... 13

Table 3-4. Cost Summary: Alternative B (Stand-Alone System Using CPVC) for a New $3338 \mathrm{ft}^{2}\left(310 \mathrm{~m}^{2}\right)$ Single Family Colonial House ............................................................ 14

Table 3-5. Cost Summary: Alternative B (Stand-Alone System Using CPVC) for a New $2257 \mathrm{ft}^{2}\left(210 \mathrm{~m}^{2}\right)$ Single Family Townhouse .............................................................. 15

Table 3-6. Cost Summary: Alternative B (Stand-Alone System Using CPVC) for a New $1171 \mathrm{ft}^{2}\left(109 \mathrm{~m}^{2}\right)$ Single Family Ranch House.............................................................. 16

Table 3-7. Cost Summary: Alternative C (Stand-Alone System Using CPVC) for a New $3338 \mathrm{ft}^{2}\left(310 \mathrm{~m}^{2}\right)$ Single Family Colonial House .......................................................... 17

Table 3-8. Cost Summary: Alternative C (Stand-Alone System Using CPVC) for a New $2257 \mathrm{ft}^{2}\left(210 \mathrm{~m}^{2}\right)$ Single Family Townhouse

Table 3-9. Cost Summary: Alternative C (Stand-Alone System Using CPVC) for a New $1171 \mathrm{ft}^{2}\left(109 \mathrm{~m}^{2}\right)$ Single Family Ranch House

Table 3-10. Cost Summary: Alternative D (Stand-Alone System Using CPVC) for a New $3338 \mathrm{ft}^{2}\left(310 \mathrm{~m}^{2}\right)$ Single Family Colonial House.

Table 3-11. Cost Summary: Alternative D (Stand-Alone System Using CPVC) for a New $2257 \mathrm{ft}^{2}\left(210 \mathrm{~m}^{2}\right)$ Single Family Townhouse ................................................................ 25

Table 3-12. Cost Summary: Alternative D (Stand-Alone System Using CPVC) for a New $1171 \mathrm{ft}^{2}\left(109 \mathrm{~m}^{2}\right)$ Single Family Ranch House.............................................................. 27

Table 3-13. Cost Estimate Summary Table, Before Markups and Inspection........................... 29

Table 3-14. Cost Estimate Summary Table at 10 \% Material Markup..................................... 30

Table 3-15. Cost Estimate Summary Table at 20 \% Material Markup.................................... 30

Table 3-16. Cost Estimate Summary Table at 30 \% Material Markup..................................... 30 
Table 3-17. Cost Estimate Summary Table at 50 \% Material Markup............................................ 30

Table 3-18. Cost Estimate Summary Table at 100 \% Material Markup.......................................... 30

Table 3-19. Present Value of \$ 100 Inspection by Study Period and Discount Rate ................... 31

Table 3-20. Present Value of \$ 200 Inspection by Study Period and Discount Rate ................... 31

Table 4-1. Least-Cost Sprinkler Alternatives by House type ……………………….................... 33

\section{List of Figures}

Figure A-1. Prototypical Colonial House: Basement Floorplan.................................................... 37

Figure A-2. Prototypical Colonial House: 1st Floor Floorplan ...................................................... 38

Figure A-3. Prototypical Colonial House: 2nd Floor Floorplan ..................................................... 39

Figure A-4. Prototypical Townhouse Floorplans.................................................................... 40

Figure A-5. Prototypical Ranch Floorplan................................................................................. 41

Figure B-1. Stand-Alone Fire Sprinkler Installation in Colonial House Basement...................... 43

Figure B-2. Stand-Alone Fire Sprinkler Installation in Colonial House 1st Floor ........................ 44

Figure B-3. Stand-Alone Fire Sprinkler Installation in Colonial House 2nd Floor...................... 45

Figure B-4. Stand-Alone Fire Sprinkler Installation in Townhouse Basement ............................. 46

Figure B-5. Stand-Alone Fire Sprinkler Installation in Townhouse 1st \& 2nd Floors................. 47

Figure B-6. Stand-Alone Fire Sprinkler Installation in Ranch ...................................................... 48

Figure C-1. Multipurpose Network Fire Sprinkler Installation in Colonial House Basement .... 49

Figure C-2. Multipurpose Network Fire Sprinkler Installation in Colonial House 1st Floor...... 50

Figure C-3. Multipurpose Network Fire Sprinkler Installation in Colonial House 2nd Floor .... 51

Figure C-4. Multipurpose Network Fire Sprinkler Installation in Townhouse ............................ 52

Figure C-5. Multipurpose Network Fire Sprinkler Installation in Ranch..................................... 53 



\section{Introduction}

\subsection{Background}

Since the 1975 introduction of the residential sprinkler standard 13D by the National Fire Protection Association (NFPA), residential sprinkler systems have proven themselves as life safety systems. According to the Residential Fire Safety Institute, there are now at least 270 communities in the United States with regulations requiring residential sprinkler systems. ${ }^{1}$ While there is growing recognition of the enhanced ability of residential sprinkler systems to protect life and property from fires, in the year 2003 less than $2 \%$ of all existing one and two family homes included a sprinkler system. $^{2}$

According to the United States Fire Administration (USFA), in 2004 there were a total of 410500 residential fires ${ }^{3}$ and a total of 117 firefighter deaths ${ }^{4}$ with an average of $41 \%$ of all firefighter deaths resulting from residential fires. ${ }^{5}$ In 2004, residential fires caused 3225 deaths, accounting for $83 \%$ of all fire deaths. ${ }^{6}$ Residential fires also were responsible for 14175 injuries and \$ 5.9 billion in direct property losses in 2004 according to the NFPA.

A study based on 15 years of data from Scottsdale, Arizona categorized fire damage in two types of homes - those with fire sprinkler systems and those without fire sprinkler systems. Property loss due to a fire in a residential home with a sprinkler system was \$ 2166 compared to \$ 45019 in the homes without a sprinkler system. ${ }^{7}$ A study based on 12 years of data from Prince George’s County, Maryland reported fire damage in homes with sprinkler systems and estimated what the damage would have been in those same houses had there not been a fire sprinkler system. Fire damage in homes with sprinkler systems amounted to \$ 3429 per reported fire incident, compared to a potential loss of \$ 326752 per incident had the homes not been equipped with a sprinkler system. ${ }^{8}$ A possible cause of the difference in damage is that the Prince George's County houses with sprinkler systems were generally new, larger and so relatively more expensive to repair than the Arizona houses without sprinkler systems.

\subsection{Purpose and Scope of Approach}

This report designs and applies a life-cycle cost (LCC) analysis consistent with the ASTM International standard method E917-02 to two basic types of sprinkler system designs allowed by NFPA 13D—a stand-alone residential sprinkler system and a multipurpose system using a network design. Life-cycle costs include design, installation in new construction, and maintenance costs.

\footnotetext{
${ }^{1}$ www.firesafehome.org Note that these jurisdictions can encompass more than one city.

${ }^{2}$ www.usfa.fema.gov/downloads/pdf/nrfsi-03report.pdf

${ }^{3}$ www.usfa.fema.gov/statistics/national/residential.shtm

${ }^{4}$ www.usfa.fema.gov/statistics/quickstats/

${ }^{5}$ www.usfa.fema.gov/downloads/pdf/nrfsi-03report.pdf

${ }^{6}$ www.nfpa.org

${ }^{7}$ Data are based on fires from 1998 to 2001. The 15-year data do not separate residential fire damage from all structures with fires. Highlights from the 15-year study are online at www.homefiresprinkler.org/ FireService/ Scottsdale15.html

${ }^{8}$ Siarnicki, Ronald Jon, Residential Sprinklers: One Community's Experience Twelve Years After Mandatory Implementation. Jan. 2001. Data are based on fires from 1992 to 2000.
} 
The life-cycle costs of three stand-alone sprinkler systems and one multipurpose network system are compared in each of three house designs. The stand-alone design uses a dedicated water supply and piping in which water only flows when the sprinkler system is activated. The multipurpose network design connects to the regular water supply and piping of the house, so water is continually circulated. The stand-alone installers used chlorinated polyvinyl chloride (CPVC) pipe. The multipurpose network system installers used crosslinked polyethylene (PEX) tubing. Throughout this report, the term "pipe" will be used to refer to both the CPVC pipe and the PEX tubing.

Chapter 2 describes the economic model, links it to the LCC method found in ASTM E917-02, and develops the cost categories needed to perform the economic analysis in this report.

Chapter 3 introduces the two sprinkler system types (multipurpose network and stand-alone) and develops estimates for the life-cycle costs of each type, for each prototypical house design. Chapter 3 applies the methodology developed in Chapter 2 to the cost data and identifies the least-cost fire sprinkler alternative for each of the three house styles.

Chapter 4 summarizes the economic analysis and recommends future research for analyzing the benefits of fire sprinklers.

Appendix A depicts floorplans of three prototypical houses designed by the Building and Fire Research Laboratory (BFRL). Appendix B depicts the design of a stand-alone fire sprinkler system. Appendix $\mathrm{C}$ depicts the design of a multipurpose network fire sprinkler system. 


\section{Comparison Methodology}

This chapter is organized as follows: Section 2.1 introduces Life-Cycle Cost (LCC) and applies it to residential fire sprinkler systems. Section 2.2 describes the alternatives and house types. Section 2.3 explains how the cost estimations will be constructed using the data in this report.

\subsection{Introduction to Life-Cycle Cost (LCC) Method}

The first costs of fire sprinkler systems are the material purchase costs and the design and installation labor costs. Even though these costs are of major importance, there are also future costs associated with ownership and operation that should be considered in an economic analysis. The life-cycle cost method is uniquely suited to evaluating not only first costs but all costs of acquiring, owning and disposing of a building or a building system over a given time period. It entails computing the LCCs for alternative systems, serving the same purpose, and then comparing them to determine which has the lowest LCC.

To be able to add and compare time-distributed costs, they have to be measured at the same point in time. To make future costs time-equivalent, that is, to take the time value of money into account, they have to be discounted to present value. The time period over which future costs are discounted is the analysis study period. For a homeowner, the study period may be the time from purchase to the sale of the house. If the time at which the analysis is performed and the costs are evaluated is the time of purchase and installation of the system, first costs do not need to be discounted.

The above approach has been standardized in the ASTM International standard practice E917-02, "Standard Practice for Measuring Life-Cycle Costs of Buildings and Building Systems." According to this standard, LCC computes "the sum of all relevant costs associated with owning and operating a building or building system over a specified time period.” Included are costs of “designing, purchasing/leasing, constructing/installing, operating, maintaining, repairing, replacing, and disposing."

The LCC to the homeowner of sprinkler alternative "X" may be represented as follows: 


$$
\begin{aligned}
& \text { LCC }_{X}=\text { First } \operatorname{cost}_{X}+ \\
& \sum_{t=0}^{T}\left[\frac{\text { O\&M }_{X t}+\text { Repair }_{X t}+\text { Replacement }_{X t}+\text { Disposal }_{X t}}{(1+d)^{t}}\right] \text {, }
\end{aligned}
$$

First cost is calculated as shown in equation 2-2.

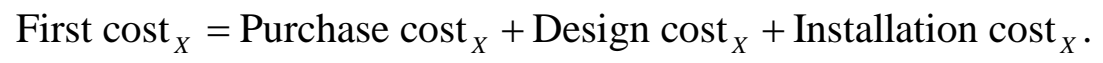

(Equation 2-2)

Sprinkler system alternatives are compared using Equation 2-3.

$\Delta \mathrm{LCC}_{Y X}=\mathrm{LCC}_{X}-\mathrm{LCC}_{Y}$,

(Equation 2-3)

where $\Delta \mathrm{LCC}_{Y X}$ is the present value of the net difference of the LCC of sprinkler alternative $Y$ over alternative $X$ for the homeowner. Sprinkler alternative $Y$ is more cost-effective than alternative $X$ if $\Delta \mathrm{LCC}_{Y X}$ is positive. Sprinkler alternative $X$ is more cost-effective than alternative $Y$ if $\Delta \mathrm{LCC}_{Y X}$ is negative.

Costs that occur in both sprinkler alternatives $\mathrm{X}$ and $\mathrm{Y}$ will be subtracted from each other, as indicated by equation 2-3. If these costs are identical, they do not contribute to differentiation between the two alternatives. This report estimates all explicit life-cycle costs that contribute to cost differences and does not include life-cycle costs that are considered identical between alternatives. Additionally, major system components, except sprinkler heads, might function for as long as 100 years. ${ }^{9}$ Therefore, it is not necessary to build into the cost estimate an expected repair or replacement cost for those components if the study period is less than 100 years.

Some intangible factors could not be quantified and therefore are not represented in Equation 2-1. The ease of building an addition is one such factor. Homeowners who build additional rooms could find it difficult to connect more fire sprinklers to a multipurpose network system, because the multipurpose network system is installed as a system with many loops and returns combined with the plumbing.

${ }^{9}$ The assumed maximum product life is based on information from product manufacturers and installers. 


\subsection{Sprinkler Alternatives}

Cost estimations were based on data obtained from sprinkler system manufacturers and installers. The basic systems contained in this report are all assumed to meet the NFPA 13D standard, with no system encountering a higher failure rate or requiring more maintenance or service.

One sprinkler alternative (Alternative A) is a multipurpose network sprinkler design that uses crosslinked polyethylene (PEX) pipe, and three sprinkler alternatives (Alternatives B, C and D) are stand-alone sprinkler designs that use chlorinated polyvinyl chloride (CPVC) pipe. There are three stand-alone alternatives in this report because three installers each returned detailed cost estimates for stand-alone systems. These systems differed in the layout of the pipe; the placement, coverage, and number of sprinkler heads; and required hours to design and install the system. ${ }^{10}$

The stand-alone designs use a dedicated water supply and piping in which water only flows when the sprinkler systems are activated. The multipurpose network design connects to the regular domestic plumbing system of the house, so water is continually circulated.

Alternatives $\mathrm{C}$ and $\mathrm{D}$ have additional cost data that provides for the inclusion of a backflow preventer (BFP), a device that ensures that water in the fire sprinkler piping does not flow back into the rest of the domestic water system. Accordingly, cost estimates have been prepared for eight AlternativesA, B, C without BFP, C with BFP, D without BFP and D with BFP. The LCC of each sprinkler alternative are estimated for a set of three NIST-designed prototypical houses (colonial, townhouse and ranch).

Table 2-1 shows the organization of the cost estimates by sprinkler alternative and house type, and the corresponding list of tables as they appear in Chapter 3.

Table 2-1: List of Cost Estimation Tables by Fire Sprinkler System and House Type

\begin{tabular}{|l|c|c|c|}
\hline \multirow{2}{*}{ Fire Sprinkler System } & \multicolumn{3}{|c|}{ House Type } \\
\cline { 2 - 4 } & Colonial & Townhouse & Ranch \\
\hline A Multipurpose Network & Table 3-1 & Table 3-2 & Table 3-3 \\
\hline B: Stand-alone \#1 & Table 3-4 & Table 3-5 & Table 3-6 \\
\hline C: Stand-alone \#2 (with and without BFP) ${ }^{1}$ & Table 3-7 & Table 3-8 & Table 3-9 \\
\hline D: Stand-alone \#3 (with and without BFP) & Table 3-10 & Table 3-11 & Table 3-12 \\
\hline $\begin{array}{l}\text { 1 These systems' costs can be estimated both with and without a backflow preventer (BFP). The } \\
\text { specified tables identify costs that must be added when a BFP is included in the system. }\end{array}$ \\
\hline
\end{tabular}

\subsection{Cost Comparison}

The next chapter estimates the cost of each alternative for each house type, and then compares the estimated cost of each alternative in the same type of house. For each house type, there are a total of six cost estimations. When backflow preventers are not required, all six cost estimates can be compared to find the least-cost system. When local regulations require backflow preventers in stand-

10 The system designers chose the starting point of the connections. 
alone systems, Alternatives B, C (without BFP) and D (without BFP) cannot be included in the cost comparisons.

The cost of Alternatives $\mathrm{C}$ and $\mathrm{D}$ with backflow preventers depends on additional analysis parameters. These parameters are (1) the annual inspection cost of the backflow preventer; (2) the study period and (3) the discount rate. The study period and discount rate parameters are required only if the backflow preventer is included.

Backflow preventers are not required by NFPA 13D. NFPA 13D (2002) Section A.6.2 states that "the connection to city mains for fire protection is often subject to local regulation of metering and backflow prevention requirements." Such a regulation could require the inclusion of a backflow preventer. This report estimates the cost of purchasing and installing a backflow preventer in Alternatives $\mathrm{C}$ and $\mathrm{D}$. A generally recommended regimen would require a yearly inspection of the backflow preventer by a professional. ${ }^{11}$

The presence of a backflow preventer in a fire sprinkler system results in future inspection costs that would not be present in a multipurpose network system. These future costs are included in the LCC calculation (Equation 2-1). The second term on the right-hand side of Equation 2-1 converts the future costs to present value. The present value of the inspections depends upon the length of the study period and the discount rate.

Equation 2-4 shows the second term on the right-hand side of Equation 2-1 when only annual inspection costs are included.

Present Value of Inspection Costs $=\sum_{t=0}^{T}\left[\frac{\text { Annual Inspection Cost }}{(1+d)^{t}}\right]$.

(Equation 2-4)

The formula for calculating the present value of a series of uniform amounts is as follows:

Present Value of Inspection Costs =Annual Inspection Cost $\cdot\left[\frac{(1+d)^{T}-1}{d \cdot(1+d)^{T}}\right]$,

(Equation 2-5)

where Annual Inspection Cost is the estimated cost for a professional inspector to verify proper operation of the backflow preventer, $d$ is the annual discount rate, and $T$ is the length of the study period in years.

The next chapter develops cost data and compares them based on the analysis presented in this chapter.

\footnotetext{
${ }^{11}$ The backflow preventer is not required by NFPA 13D. The inspection regimen is also not required by NFPA 13D or by local regulation. A manufacturer or installer, on the other hand, might require an inspection regimen in order to retain warranty coverage, for example.
} 


\section{Sprinkler Cost Analysis}

\subsection{Introduction}

Cost estimations were developed based on data obtained from sprinkler system manufacturers and installers. One sprinkler alternative (Alternative A) is a multipurpose network sprinkler design that uses crosslinked polyethylene (PEX) pipe. The other sprinkler alternatives (Alternatives B, C and D) are stand-alone sprinkler designs that use chlorinated polyvinyl chloride (CPVC) pipe. The cost of each sprinkler alternative is estimated for a set of three NIST-designed prototypical houses (colonial, townhouse and ranch). The stand-alone design uses a dedicated water supply and piping in which water only flows when the sprinkler system is activated. The multipurpose network design connects to the regular domestic water supply and piping of the house, so water is continually circulated.

NIST researchers requested details from installers regarding design costs, material purchase costs, installation hours as well as operation, maintenance, repair, and inspection costs. Installation plans, a comprehensive list of required components, and material cost data obtained from manufacturers and sprinkler system installers are presented in tables later in this chapter.

The combination of different house sizes and layouts, plus the use of different piping materials and sprinkler installation methods, produces a range of cost estimates. System configuration differed according to the house layout: a $3338 \mathrm{ft}^{2}\left(310 \mathrm{~m}^{2}\right)$ two-story colonial with basement, a $2257 \mathrm{ft}^{2}$ $\left(210 \mathrm{~m}^{2}\right)$ three-story townhouse, and a $1171 \mathrm{ft}^{2}\left(109 \mathrm{~m}^{2}\right)$ 1-story ranch. ${ }^{12}$ These NIST-designed prototypical houses are represented in Appendix A. A stand-alone system is reproduced in Appendix $\mathrm{B}$; and an integrated network design in Appendix C.

\subsection{Purchase and Installation Cost Estimates}

The cost estimations in this chapter are based largely on designs and costs provided by experts in sprinkler system design and installation. Each expert itemized the components necessary for the system and provided bare material costs. Design costs were estimated in either dollar terms or in hours. The installation cost was estimated from the labor hours necessary to install the sprinkler systems.

The experts who provided these tables were asked to identify all items that should be included in a system that meets NFPA 13D. Costs that are specifically excluded as superfluous to the core design are: service entrance materials from the water main to the distribution manifold, domestic hot and cold water plumbing system piping and material, final connections to plumbing fixtures and hose bibs.

Certain situations require additional costs. For example a small number of jurisdictions might require a separate water system to the curb, perhaps even including a water meter. Rural developments might be unable to meet requirements without installing a tank, pump, and backup electric generator. While these situations could arise, in this analysis they were not considered typical and therefore costs related to these scenarios were not estimated.

\footnotetext{
${ }^{12}$ The colonial square footage does not include the garage.
} 
The level of protection is based on the minimum standard required by NFPA 13D. Certain bathrooms and closets, for example, are not required to be covered. Experts used different types of pipe layouts and different numbers and types of sprinkler heads to achieve the NFPA 13D standard. Therefore, there is variation over the designs in the number of sprinkler heads and the length and type of pipe required.

Extraneous costs - costs for items not required by NFPA 13D-were not included in the analysis. For example, the cost of extra sprinkler heads was removed from all cost estimates that had originally provided them.

In this report, operation and maintenance costs are considered identical between alternative sprinkler systems, except when a backflow preventer is used. According to NFPA 25 (Inspection, Testing and Maintenance of Water-Based Fire Protection Systems), control valves without electronic supervision should be checked on a weekly basis, just to make sure that they are in the open position. The most rigorous maintenance recommendation requires a full sprinkler system inspection performed four times during the year. This inspection is accomplished by the homeowner and is not included in the life-cycle cost estimate.

Backflow preventers might reasonably be inspected every year by a professional at an estimated cost of \$ 100 to $\$ 200 .^{13}$ This inspection cost is a significant operation and maintenance cost included with Alternatives C (with BFP) and D (with BFP).

\subsection{Cost Data}

The following 12 tables, organized as shown in Table 2-1, present the sprinkler alternatives in three house types. The multipurpose network alternative appears first, followed by the three stand-alone alternatives. Each alternative contains three sprinkler designs, encompassing a residential fire sprinkler system in a colonial, townhouse and ranch house. Each table itemizes the material and labor costs for a single cost estimation — specifically, a single alternative fire sprinkler system in a single house.

Tables 3-1, 3-2 and 3-3 detail the estimated cost of installing the multipurpose network system using PEX (Alternative A) in a colonial house, townhouse and ranch house. This system was designed using a $65 \mathrm{lb} / \mathrm{in}^{2}$ (448 kPa) static water supply, but is valid to as low as $45 \mathrm{lb} / \mathrm{in}^{2}$ (310 kPa). The multipurpose network layout is installed as a system and includes the cold-water piping for the houses. Therefore, a correction has been applied to remove the costs related to the domestic cold water system.

The estimated cost of Alternative B, a stand-alone system without a backflow preventer, is shown in Tables 3-4, 3-5 and 3-6. The cost estimate tables are arranged with the colonial house first, next the townhouse, and finally the ranch house. The estimated cost of Alternative $C$ is presented in Tables 3-7, 3-8 and 3-9; and Alternative D in 3-10, 3-11, and 3-12. Stand-alone systems in this report do not include the materials and labor necessary for the cold-water system.

\footnotetext{
${ }^{13}$ This covers the range in prices quoted for a service call and inspection of the backflow preventer, obtained from fire sprinkler system installers including those contributing to this study.
} 
Each table lists two cost categories: Material and Labor. The Material category includes the subcategories of Fire Sprinklers, Pipe and Fittings, Accessories and Miscellaneous, Valves, and optional Backflow Preventers (when specified). Labor includes Design and Installation Labor. The total Material and Labor cost estimate is shown at the bottom right of the table.

In Table 3-1, underneath the heading "Sprinkler System Cost Component” in the first column, the word "Material" is bolded and centered. Listed directly underneath are all the materials required for the sprinkler system, organized into three subgroupings. Each subgroup is bolded and aligned on the left margin.

In Table 3-1, The first material subgroup is “Fire Sprinklers.” Under this heading, the fire sprinkler pendant assemblies are listed. Because this is a material component, quantity and cost data are shown to the right. Column 2, "quantity," indicates that 24 pendant assemblies are required. Column 3, "units,” indicates that pendant assembly cost is given per unit, or "each.” Column 4, "bare material cost per unit," shows that each pendant assembly unit costs \$ 25.03 without any markup. Column 5, "total bare material cost," multiplies the quantity of pendant assemblies by the bare material cost per assembly unit. As there are no more entries under the subgroup "Fire Sprinklers," the material list proceeds to the second subgroup, "Pipe and Fittings," again bolded and aligned on the left margin. The details and costs of the six listed materials follow the same convention as that for the sprinkler pendant assemblies. Lastly, the subgroup "Accessories” is shown, for which there is one entry for hangers.

All the individual items' total bare material costs are now added together. The "Total Bare Material Cost” amount is shown in column 5. In Table 3-1, this amount is \$ 1024.78 .

The next section identifying labor cost is identified by the word "Labor" bolded and centered in the first column. Under this section are lines for two types of labor cost-design and installationfollowed by a line for the total. The column 1 description for design includes the number of hours and rate used in the calculation, if available. The dollar amount is shown in column 6, "labor cost." The next line is for the installation cost, again described in column 1 with the number of hours and the rate used in the calculation. The dollar amount is again shown in column 6 . These two numbers are totaled and given in the next line, “Total Labor Cost," shown in column 6. In Table 3-1, this amount is \$ 576.00 .

The final lines of the table report the total bare material and labor cost. This part of the table is identified by the word "Totals" bolded and centered in the first column. The line directly underneath in column 1, "Total Material and Labor Cost" indicates the sum of the total bare material cost and labor cost. The amount is found in column 7, "combined material and labor cost." In Table 3-1, this amount is \$ 1600.78 .

Tables 3-1, 3-2 and 3-3 require that the cost of the residential cold-water system be deducted from this total. For the estimate without the residential cold-water system, one-third of the combined pipe and 2 hours of installation labor were subtracted. This correction is shown in the last line of the affected tables, identified as "Total Material and Labor Cost without cold water system" in column 1. Column 5, "total bare material cost," shows the reduction in material cost; and column 6, "labor cost," shows the reduction in labor cost. These reductions are formatted as dollar amounts inside parenthesis, indicating negative dollar amounts. These negative adjustments reduce the previous cost estimates. Column 7, “combined material and labor cost” contains the corrected total. In Table 3-1, this amount is $\$ 1419.78$. 
Tables 3-7 through 3-12 contain a "backflow preventer" material cost subgroup. This group appears after the "Accessories" subgroup. Materials listed under this group would be required if a backflow preventer were to be included as part of the fire sprinkler system. Tables 3-7 through 3-12 contain extra lines to facilitate calculations both with and without the backflow preventer (BFP) and associated material and labor. The "Total Bare Material Costs" are now given on two lines. The first line is labeled "Total Bare Material Costs without BFP" in column 1. The dollar value is given in column 5. In Table 3-7, this amount is $\$ 463.60$, identifying the total bare cost of materials for a colonial house system of Alternative $\mathrm{C}$, without including the backflow preventer. The line underneath, labeled "Total Bare Material Costs with BFP" in column 1, identifies in column 5 the total bare cost of materials when a backflow preventer is included. In Table 3-7, this amount is \$ 851.27.

Similarly, there are two lines to identify the two installation costs in the "Labor" section. Under this section are now two lines for installation cost. (Design costs are not affected.) The description in column 1 includes the number of hours and the rate used in the calculation. The dollar amount is shown in column 6. To accommodate the two installation costs, two labor totals are reported. Total Labor Cost is given on two lines, first without the backflow preventer and then with the backflow preventer. In Table 3-7, the first amount is \$ 966.00 and the second is \$1 030.00.

The table concludes with two lines in the "Total" section. The first line adds the bare material cost and labor cost when backflow preventers are not installed, and the second line adds the bare material cost and labor cost when backflow preventers are installed. The dollar amounts are given in column 7. In Table 3-7, the first amount is \$ 1429.60 and the second is \$ 1881.27 . 
Table 3-1. Cost Summary: Alternative A (Multipurpose Network System Using PEX) for a New $3338 \mathrm{ft}^{2}$ (310 m²) Single Family Colonial House

\begin{tabular}{|c|c|c|c|c|c|c|}
\hline $\begin{array}{l}\text { Sprinkler System } \\
\text { Cost Component }\end{array}$ & quantity & units & $\begin{array}{r}\text { bare material } \\
\text { cost per unit }\end{array}$ & $\begin{array}{r}\text { total bare } \\
\text { material cost } \\
\end{array}$ & $\begin{array}{r}\text { labor } \\
\text { cost }\end{array}$ & $\begin{array}{r}\text { combined material } \\
\text { \& labor cost }\end{array}$ \\
\hline \multicolumn{7}{|l|}{ Material } \\
\hline \multicolumn{7}{|l|}{ Fire Sprinklers } \\
\hline F1/Res $49\left(155^{\circ} \mathrm{F}\right)$ Recessed Pendent Assembly, White & 24 & each & $\$ 25.03$ & $\$ 600.60$ & & \\
\hline \multicolumn{7}{|l|}{ Pipe and Fittings } \\
\hline $1 / 2$ in PEX - white, $1000 \mathrm{ft}$ coil & 1 & $1000 \mathrm{ft}$ & 270.00 & 270.00 & & \\
\hline 1/2 in PEX - white, $300 \mathrm{ft}$ coil & 1 & $300 \mathrm{ft}$ & 81.00 & 81.00 & & \\
\hline 1 in Copper Branch Manifold, 10 outlets & 1 & each & 26.63 & 26.63 & & \\
\hline PEX Ring $1 / 2$ in (blue print) & 150 & each & 0.06 & 8.25 & & \\
\hline PEX Brass Tee, $1 / 2$ in PEX $x$ 1/2 in PEX & 10 & each & 1.45 & 14.50 & & \\
\hline \multicolumn{7}{|l|}{ Accessories } \\
\hline Hangers (1/2 in, 5/8 in, 3/4 in PEX) & 4 & each & 5.95 & 23.80 & & \\
\hline Total Bare Material Cost & & & & 1024.78 & & \\
\hline & & & & & & \\
\hline \multicolumn{7}{|l|}{ Labor } \\
\hline Design Cost (4 hours at $\$ 40.00$ per hour) & & & & & $\$ 160.00$ & \\
\hline Installation Cost (13 hours at \$ 32.00 per hour) & & & & & 416.00 & \\
\hline Total Labor Cost & & & & & 576.00 & \\
\hline & & & & & & \\
\hline \multicolumn{7}{|l|}{ Totals } \\
\hline Total Material and Labor Cost & & & & & & $\$ 1600.78$ \\
\hline Total Material and Labor Cost without cold water system & & & & $(117.00)$ & $(64.00)$ & 1419.78 \\
\hline
\end{tabular}

Where possible, generic product descriptions have been substituted for product trade names. Material prices do not include any markup to cover overhead and profit. Labor cost is based on manufacturer's estimation that it would take a 2-person crew 13 hours total to install the system. The sprinkler fitter and plumber trades are estimated at \$ 32.00 per hour (2005 National Construction Estimator, accessed at www.get-a-quote.net). Design cost of $\$ 40$ per hour is provided by manufacturer. Extra sprinkler heads and cabinet exceeding the minimum requirements of NFPA 13D were removed from original estimate. For the estimate without the cold water system, one-third of the combined pipe and 2 hours of installation labor are subtracted. 
Table 3-2. Cost Summary: Alternative A (Multipurpose Network System Using PEX) for a New $2257 \mathrm{ft}^{2}\left(210 \mathrm{~m}^{2}\right)$ Single Family Townhouse

\begin{tabular}{|c|c|c|c|c|c|c|}
\hline $\begin{array}{l}\text { Sprinkler System } \\
\text { Cost Component }\end{array}$ & quantity & units & $\begin{array}{r}\text { bare material } \\
\text { cost per unit }\end{array}$ & $\begin{array}{r}\text { total bare } \\
\text { material cost }\end{array}$ & $\begin{array}{r}\text { labor } \\
\text { cost }\end{array}$ & $\begin{array}{r}\text { combined material } \\
\text { \& labor cost }\end{array}$ \\
\hline \multicolumn{7}{|l|}{ Material } \\
\hline \multicolumn{7}{|l|}{ Fire Sprinklers } \\
\hline F1/Res $49\left(155^{\circ} \mathrm{F}\right)$ Recessed Pendent Assembly & 22 & each & $\$ 25.03$ & $\$ 550.55$ & & \\
\hline \multicolumn{7}{|l|}{ Pipe and Fittings } \\
\hline 1/2 in PEX - white, $1000 \mathrm{ft}$ coil & 1 & $1000 \mathrm{ft}$ & 270.00 & 270.00 & & \\
\hline 1/2 in PEX - white, $100 \mathrm{ft}$ coil & 1 & $100 \mathrm{ft}$ & 27.00 & 27.00 & & \\
\hline 1 in Copper Branch Manifold, 12 outlets & 1 & each & 32.23 & 32.23 & & \\
\hline PEX Ring 1/2 in (blue print) & 150 & each & 0.06 & 8.25 & & \\
\hline PEX Brass Tees, 1/2 in PEX x 1/2 in PEX & 10 & each & 1.45 & 14.50 & & \\
\hline \multicolumn{7}{|l|}{ Accessories } \\
\hline Hangers (1/2 in, 5/8 in, 3/4 in PEX) & 3 & each & 5.95 & 17.85 & & \\
\hline & & & & & & \\
\hline \multirow[t]{2}{*}{ Total Bare Material Cost } & & & & 920.38 & & \\
\hline & & & & & & \\
\hline \multicolumn{7}{|l|}{$\begin{array}{ll}\text { Labor } \\
\end{array}$} \\
\hline Design Cost (4 hours at $\$ 40.00$ per hour) & & & & & $\$ 160.00$ & \\
\hline Installation Cost (12 hours at \$ 32.00 per hour) & & & & & 384.00 & \\
\hline \multirow[t]{2}{*}{ Total Labor Cost } & & & & & 544.00 & \\
\hline & & & & & & \\
\hline \multicolumn{7}{|l|}{$\begin{array}{r}\text { Totals } \\
\end{array}$} \\
\hline Total Material and Labor Cost & & & & & & $\$ 1464.38$ \\
\hline Total Material and Labor Cost without cold water system & & & & $(99.00)$ & $(64.00)$ & 1301.38 \\
\hline
\end{tabular}

Where possible, generic product descriptions have been substituted for product trade names. Material prices do not include any markup to cover overhead and profit. Labor cost is based on manufacturer’s estimation that it would take a 2-person crew 12 hours total to install the system. The sprinkler fitter and plumber trades are estimated at $\$ 32.00$ per hour (2005 National Construction Estimator, accessed at www.get-a-quote.net). Design cost of $\$ 40$ per hour is provided by manufacturer. Extra sprinkler heads and cabinet exceeding the minimum requirements of NFPA 13D were removed from original estimate. For the estimates without the cold water system, one-third of the combined pipe and 2 hours of installation labor are subtracted. 
Table 3-3. Cost Summary: Alternative A (Multipurpose Network System Using PEX) for a New $1171 \mathrm{ft}^{2}$ (109 m²) Single Family Ranch House

\begin{tabular}{|c|c|c|c|c|c|c|}
\hline $\begin{array}{l}\text { Sprinkler System } \\
\text { Cost Component }\end{array}$ & quantity & units & $\begin{array}{r}\text { bare material } \\
\text { cost per unit }\end{array}$ & $\begin{array}{r}\text { total bare } \\
\text { material cost } \\
\end{array}$ & $\begin{array}{r}\text { labor } \\
\text { cost }\end{array}$ & $\begin{array}{r}\text { combined material } \\
\text { \& labor cost }\end{array}$ \\
\hline \multicolumn{7}{|l|}{ Material } \\
\hline \multicolumn{7}{|l|}{ Fire Sprinklers } \\
\hline F1/Res $49\left(155^{\circ} \mathrm{F}\right)$ Recessed Pendent Assembly, White & 9 & each & $\$ 25.03$ & $\$ 225.23$ & & \\
\hline \multicolumn{7}{|l|}{ Pipe and Fittings } \\
\hline $1 / 2$ in PEX plus - white, $300 \mathrm{ft}$ coil & 1 & $300 \mathrm{ft}$ & 81.00 & 81.00 & & \\
\hline 1/2 in PEX plus - white, $100 \mathrm{ft}$ coil & 1 & $100 \mathrm{ft}$ & 27.00 & 27.00 & & \\
\hline 1 in Copper Branch Manifold, 8 outlets & 1 & each & 21.98 & 21.98 & & \\
\hline PEX Ring $1 / 2$ in (blue print) & 100 & each & 0.06 & 5.50 & & \\
\hline PEX Brass Tees, $1 / 2$ in PEX $x$ 1/2 in PEX & 10 & each & 1.45 & 14.50 & & \\
\hline \multicolumn{7}{|l|}{ Accessories } \\
\hline Hangers (1/2 in, 5/8 in, 3/4 in PEX) & 1 & each & 5.95 & 5.95 & & \\
\hline Total Bare Material Cost & & & & 381.16 & & \\
\hline & & & & & & \\
\hline \multicolumn{7}{|l|}{ Labor } \\
\hline Design Cost (4 hours at $\$ 40.00$ per hour) & & & & & $\$ 160.00$ & \\
\hline Installation Cost (5 hours at \$ 32.00 per hour) & & & & & 160.00 & \\
\hline Total Labor Cost & & & & & 320.00 & \\
\hline & & & & & & \\
\hline \multicolumn{7}{|l|}{ Totals } \\
\hline Total Material and Labor Cost & & & & & & $\$ 701.16$ \\
\hline Total Material and Labor Cost w/o cold water system & & & & $(36.00)$ & $(64.00)$ & 601.16 \\
\hline
\end{tabular}

Where possible, generic product descriptions have been substituted for product trade names. Material prices do not include any markup to cover overhead and profit. Labor cost is based on manufacturer's estimation that it would take a 2-person crew 5 hours total to install the system. The sprinkler fitter and plumber trades are estimated at $\$ 32.00$ per hour (2005 National Construction Estimator, accessed at www.get-a-quote.net). Design cost of $\$ 40$ per hour is provided by manufacturer. Extra sprinkler heads and cabinet exceeding the minimum requirements of NFPA 13D were removed from original estimate. For the estimates without the cold water system, one-third of the combined pipe and 2 hours of installation labor are subtracted. 
Table 3-4. Cost Summary: Alternative B (Stand-Alone System Using CPVC) for a New $3338 \mathrm{ft}^{2}\left(310 \mathrm{~m}^{2}\right.$ ) Single Family Colonial House

\begin{tabular}{|c|c|c|c|c|c|c|}
\hline $\begin{array}{l}\text { Sprinkler System } \\
\text { Cost Component }\end{array}$ & quantity & units & $\begin{array}{r}\text { bare material } \\
\text { cost per unit }\end{array}$ & $\begin{array}{r}\text { total bare } \\
\text { material cost }\end{array}$ & $\begin{array}{r}\text { labor } \\
\text { cost }\end{array}$ & $\begin{array}{r}\text { combined material } \\
\& \text { labor cost }\end{array}$ \\
\hline \multicolumn{7}{|l|}{ Material } \\
\hline \multicolumn{7}{|l|}{ Fire Sprinklers } \\
\hline Residential Domed Heads & 19 & & $\$ 6.96$ & $\$ 132.24$ & & \\
\hline Standard Sprinklers & 4 & & 4.42 & 17.68 & & \\
\hline Head Adapter & 23 & & 0.90 & 20.70 & & \\
\hline \multicolumn{7}{|l|}{ Pipe and Fittings } \\
\hline Tee & 27 & & 0.61 & 16.47 & & \\
\hline 90 Ell & 18 & & 0.44 & 7.92 & & \\
\hline Coupling & 2 & & 0.44 & 0.88 & & \\
\hline Pipe & 250 & & 0.32 & 80.00 & & \\
\hline Straps & 50 & & 0.24 & 12.00 & & \\
\hline Riser & 1 & & 116.25 & 116.25 & & \\
\hline \multicolumn{7}{|l|}{ Miscellaneous } \\
\hline Glue/Primer & 1 & & 5.35 & 5.35 & & \\
\hline Misc. Expenses & & & 33.50 & 33.50 & & \\
\hline Total Bare Material Cost & & & & 442.99 & & \\
\hline & & & & & & \\
\hline \multicolumn{7}{|l|}{ Labor } \\
\hline Design Cost & & & & & $\$ 400.00$ & \\
\hline Installation Cost (21 hours at \$ 32.00 per hour) & & & & & 672.00 & \\
\hline Total Labor Cost & & & & & 1072.00 & \\
\hline 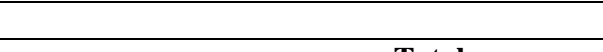 & & & & & & \\
\hline \multicolumn{7}{|l|}{$\begin{array}{rc} & \text { Totals } \\
\end{array}$} \\
\hline Total Material and Labor Cost & & & & & & $\$ 1515.00$ \\
\hline
\end{tabular}

The riser component includes a single check valve to control backflow, and also includes a flow switch, pressure gauge and ball valve for draining the system. Material prices do not include any markup to cover overhead and profit. 
Table 3-5. Cost Summary: Alternative B (Stand-Alone System Using CPVC) for a New $2257 \mathrm{ft}^{2}\left(210 \mathrm{~m}^{2}\right)$ Single Family Townhouse

\begin{tabular}{|c|c|c|c|c|c|c|}
\hline $\begin{array}{l}\text { Sprinkler System } \\
\text { Cost Component }\end{array}$ & quantity & units & $\begin{array}{r}\text { bare material } \\
\text { cost per unit }\end{array}$ & $\begin{array}{r}\text { total bare } \\
\text { material cost }\end{array}$ & $\begin{array}{r}\text { labor } \\
\text { cost }\end{array}$ & $\begin{array}{r}\text { combined material } \\
\text { \& labor cost }\end{array}$ \\
\hline \multicolumn{7}{|l|}{ Material } \\
\hline \multicolumn{7}{|l|}{ Fire Sprinklers } \\
\hline Residential Domed Heads & 19 & & $\$ 6.96$ & $\$ 132.24$ & & \\
\hline Standard Sprinklers & 4 & & 4.42 & 17.68 & & \\
\hline \multicolumn{7}{|l|}{ Pipe and Fittings } \\
\hline Head Adapter & 23 & & 0.90 & 20.70 & & \\
\hline Tee & 27 & & 0.61 & 16.47 & & \\
\hline 90 Ell & 19 & & 0.44 & 8.36 & & \\
\hline Coupling & 2 & & 0.44 & 0.88 & & \\
\hline Pipe & 250 & & 0.32 & 80.00 & & \\
\hline Straps & 50 & & 0.24 & 12.00 & & \\
\hline Riser & 1 & & 38.79 & 38.79 & & \\
\hline \multicolumn{7}{|l|}{ Miscellaneous } \\
\hline Glue/Primer & 2 & & 5.35 & 10.70 & & \\
\hline Misc Expenses & & & 33.78 & 33.78 & & \\
\hline Total Bare Material Cost & & & & 371.60 & & \\
\hline & & & & & & \\
\hline \multicolumn{7}{|l|}{ Labor } \\
\hline Design Cost & & & & & $\$ 400.00$ & \\
\hline Installation Cost (19 hours at \$ 32.00 per hour) & & & & & 608.00 & \\
\hline Total Labor Cost & & & & & 1008.00 & \\
\hline & & & & & & \\
\hline \multicolumn{7}{|l|}{$\begin{array}{ll} & \text { Totals } \\
\end{array}$} \\
\hline Total Material and Labor Cost & & & & & & $\$ 1380.00$ \\
\hline
\end{tabular}

The riser component includes a single check valve to control backflow, and also includes a flow switch, pressure gauge and ball valve for draining the system. Material prices do not include any markup to cover overhead and profit. 
Table 3-6. Cost Summary: Alternative B (Stand-Alone System Using CPVC) for a New $1171 \mathrm{ft}^{2}$ (109 m²) Single Family Ranch House

\begin{tabular}{|c|c|c|c|c|c|c|}
\hline $\begin{array}{l}\text { Sprinkler System } \\
\text { Cost Component }\end{array}$ & quantity & units & $\begin{array}{r}\text { bare material } \\
\text { cost per unit }\end{array}$ & $\begin{array}{r}\text { total bare } \\
\text { material cost }\end{array}$ & $\begin{array}{r}\text { labor } \\
\text { cost }\end{array}$ & $\begin{array}{r}\text { combined material } \\
\text { \& labor cost }\end{array}$ \\
\hline \multirow{2}{*}{\multicolumn{7}{|c|}{ Material }} \\
\hline & & & & \multicolumn{3}{|c|}{ Fire Sprinklers } \\
\hline Residential Domed Heads & 7 & & $\$ 6.96$ & $\$ 48.72$ & & \\
\hline Standard Sprinklers & 1 & & 4.42 & 4.42 & & \\
\hline \multirow{2}{*}{\multicolumn{7}{|c|}{ Pipe and Fittings }} \\
\hline Head Adapter & & & 0.90 & 7.20 & & \\
\hline Tee & 9 & & 0.61 & 5.49 & & \\
\hline 90 Ell & 6 & & 0.44 & 2.64 & & \\
\hline Coupling & 2 & & 0.44 & 0.88 & & \\
\hline Pipe & 100 & & 0.32 & 32.00 & & \\
\hline Straps & 20 & & 0.24 & 4.80 & & \\
\hline Riser & 1 & & 38.79 & 38.79 & & \\
\hline \multicolumn{7}{|l|}{ Miscellaneous } \\
\hline Glue/Primer & 1 & & 5.35 & 5.35 & & \\
\hline Misc Expenses & & & 15.03 & 15.03 & & \\
\hline \multirow{3}{*}{ Total Bare Material Cost } & & & & & & \\
\hline & & & & 165.32 & & \\
\hline & \multicolumn{6}{|c|}{ Labor } \\
\hline Design Cost & & & & & $\$ 267.00$ & \\
\hline Installation Cost (11 hours at $\$ 32.00$ per hour) & & & & & 352.00 & \\
\hline Total Labor Cost & & & & & 619.00 & \\
\hline & & & & & & \\
\hline \multicolumn{7}{|l|}{ Totals } \\
\hline Total Material and Labor Cost & & & & & & $\$ 784.00$ \\
\hline & & & & & & \\
\hline
\end{tabular}

The riser component includes a single check valve to control backflow, and also includes a flow switch, pressure gauge and ball valve for draining the system. Material prices do not include any markup to cover overhead and profit. 
Table 3-7. Cost Summary: Alternative C (Stand-Alone System Using CPVC) for a New $3338 \mathrm{ft}^{2}\left(310 \mathrm{~m}^{2}\right.$ ) Single Family Colonial House

\begin{tabular}{|c|c|c|c|c|c|c|}
\hline $\begin{array}{l}\text { Sprinkler System } \\
\text { Cost Component }\end{array}$ & quantity & units & $\begin{array}{r}\text { bare material } \\
\text { cost per unit }\end{array}$ & $\begin{array}{r}\text { total bare } \\
\text { material cost }\end{array}$ & $\begin{array}{r}\text { labor } \\
\text { cost }\end{array}$ & $\begin{array}{r}\text { combined material } \\
\text { \& labor cost }\end{array}$ \\
\hline \multicolumn{7}{|l|}{ Material } \\
\hline \multicolumn{7}{|l|}{ Fire Sprinklers } \\
\hline LFII $155^{\circ} \mathrm{F}$ White Pendant & 24 & each & $\$ 4.30$ & $\$ 103.20$ & & \\
\hline $1 / 2$ White Esc LFII & 24 & each & 0.70 & 16.80 & & \\
\hline \multicolumn{7}{|l|}{ Pipe and Fittings } \\
\hline $3 / 4$ in CPVC Pipe & 245 & linear $\mathrm{ft}$ & 0.37 & 90.82 & & \\
\hline 1 in CPVC Pipe & 35 & linear $\mathrm{ft}$ & 0.87 & 30.56 & & \\
\hline 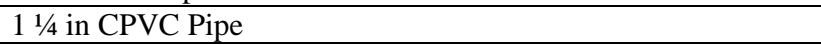 & 35 & linear $\mathrm{ft}$ & 0.90 & 31.33 & & \\
\hline $1 \frac{1 / 4}{4}$ in GALV 40 & 10 & each & 1.57 & 15.70 & & \\
\hline Galvanized Nipples & 1 & each & 5.25 & 5.25 & & \\
\hline 3/4 in CPVC Fitting Tee & 14 & each & 0.69 & 9.66 & & \\
\hline $1 \frac{11 / 4 \text { in CPVC Fittings Tee }}{}$ & 1 & each & 2.18 & 2.18 & & \\
\hline 1 in CPVC Red Tee & 6 & each & 1.18 & 7.08 & & \\
\hline $1 \frac{11 / 4 \text { in CPVC Red Tee }}{}$ & 2 & each & 2.17 & 4.34 & & \\
\hline 3/4 in CPVC 90 Ell & 30 & each & 0.51 & 15.30 & & \\
\hline 1 in CPVC 90 Ell & 2 & each & 1.12 & 2.24 & & \\
\hline 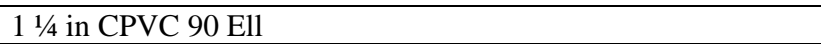 & 4 & each & 1.44 & 5.76 & & \\
\hline 1 in CPVC Cross & 2 & each & 1.35 & 2.70 & & \\
\hline $1 \frac{11 / 4}{4}$ CPVC Cross & 1 & each & 1.89 & 1.89 & & \\
\hline 3/4 in CPVC Coupling & 4 & each & 0.50 & 1.98 & & \\
\hline 1 in CPVC Coupling & 2 & each & 0.63 & 1.26 & & \\
\hline $1 \frac{1 / 4}{\text { in CPVC Coupling }}$ & 2 & each & 0.95 & 1.90 & & \\
\hline 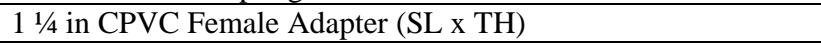 & 2 & each & 5.31 & 10.62 & & \\
\hline $3 / 4$ in CPVC Caps & 3 & each & 0.30 & 0.90 & & \\
\hline $1 \frac{11 / 4 \text { in CPVC Reduced Bushings }}{}$ & 1 & each & 0.39 & 0.39 & & \\
\hline 11/1/4 in CPVC Reduced Bushings & 5 & each & 0.60 & 3.01 & & \\
\hline $3 / 4 \times 1 / 2$ in CPVC Female Sprinkler Head Adapter (SLIP x FIPT) & 26 & each & 1.17 & 30.42 & & \\
\hline Galv Fitting Riser & 1 & each & 11.09 & 11.09 & & \\
\hline \multirow{2}{*}{\multicolumn{7}{|c|}{ Valves }} \\
\hline & & & & & & \\
\hline 3/4 in Globe Valve & 1 & each & 5.36 & 5.36 & & \\
\hline 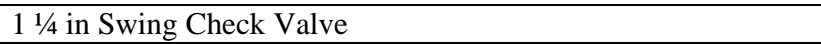 & 1 & each & 14.12 & 14.12 & & \\
\hline Hose Adapter & 1 & each & 3.12 & 3.12 & & \\
\hline
\end{tabular}


Table 3-7 (continued)

\begin{tabular}{|c|c|c|c|c|c|c|}
\hline $\begin{array}{c}\text { Sprinkler System } \\
\text { Cost Component }\end{array}$ & quantity & units & $\begin{array}{r}\text { bare material } \\
\text { cost per unit }\end{array}$ & $\begin{array}{r}\text { total bare } \\
\text { material cost }\end{array}$ & $\begin{array}{r}\text { labor } \\
\text { cost }\end{array}$ & $\begin{array}{r}\text { combined material } \\
\text { \& labor cost }\end{array}$ \\
\hline \multicolumn{7}{|l|}{ Accessories \& Miscellaneous } \\
\hline $1 \frac{1}{4}$ in Rings & 2 & each & $\$ 0.33$ & $\$ 0.66$ & & \\
\hline 3/8 in Top Beam ATR & 2 & each & 0.35 & 0.70 & & \\
\hline 3/8 in Hole Huggers & 2 & each & 0.31 & 0.62 & & \\
\hline Cement & 1 & each & 11.37 & 11.37 & & \\
\hline $1 \frac{1}{4}$ in Tolcos & 2 & each & 0.37 & 0.74 & & \\
\hline $3 / 4$ in Tolcos & 55 & each & 0.33 & 18.15 & & \\
\hline 1 in Tolcos & 7 & each & 0.34 & 2.38 & & \\
\hline \multicolumn{7}{|l|}{ Backflow Preventer (BFP) } \\
\hline Flow Switch Tee & 1 & each & 3.43 & 3.43 & & \\
\hline Flow Switch & 1 & each & 62.46 & 62.46 & & \\
\hline Alarm Bell & 1 & each & 29.85 & 29.85 & & \\
\hline PIVS Tamper & 2 & each & 68.03 & 136.06 & & \\
\hline Water Gauge (optional) & 1 & each & 9.87 & 9.87 & & \\
\hline Backflow Preventer Unit & 1 & each & 146.00 & 146.00 & & \\
\hline Total Bare Material Cost without BFP & & & & 463.60 & & \\
\hline Total Bare Material Cost with BFP & & & & 851.27 & & \\
\hline & & & & & & \\
\hline \multicolumn{7}{|l|}{ Labor } \\
\hline Design Cost & & & & & $\$ 326.00$ & \\
\hline Installation Cost without BFP (20 hours at \$ 32 per hour) & & & & & 640.00 & \\
\hline Installation Cost with BFP (22 hours at \$ 32 per hour) & & & & & 704.00 & \\
\hline Total Labor Cost without BFP & & & & & 966.00 & \\
\hline Total Labor Cost with BFP & & & & & 1030.00 & \\
\hline & & & & & & \\
\hline \multicolumn{7}{|l|}{$\begin{array}{c}\text { Totals } \\
\end{array}$} \\
\hline Total Materials and Labor Quote without BFP & & & & & & $\$ 1429.60$ \\
\hline Total Materials and Labor Quote with BFP & & & & & & 1881.27 \\
\hline 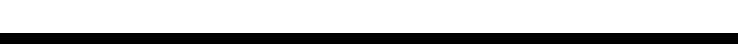 & & & & & & \\
\hline
\end{tabular}


Table 3-8. Cost Summary: Alternative C (Stand-Alone System Using CPVC) for a New $2257 \mathrm{ft}^{2}\left(210 \mathrm{~m}^{2}\right)$ Single Family Townhouse

\begin{tabular}{|c|c|c|c|c|c|c|}
\hline $\begin{array}{l}\text { Sprinkler System } \\
\text { Cost Component }\end{array}$ & quantity & units & $\begin{array}{r}\text { bare material } \\
\text { cost per unit }\end{array}$ & $\begin{array}{r}\text { total bare } \\
\text { material cost }\end{array}$ & $\begin{array}{r}\text { labor } \\
\text { cost }\end{array}$ & $\begin{array}{r}\text { combined material } \\
\text { \& labor cost }\end{array}$ \\
\hline \multicolumn{7}{|l|}{ Material } \\
\hline \multicolumn{7}{|l|}{ Fire Sprinklers } \\
\hline LFII $155^{\circ} \mathrm{F}$ White Pendant & 22 & each & $\$ 4.30$ & $\$ 94.60$ & & \\
\hline $1 / 2$ White Esc LFII & 22 & each & 0.70 & 15.40 & & \\
\hline \multicolumn{7}{|l|}{ Pipe \& Fittings } \\
\hline $3 / 4$ in CPVC Pipe & 180 & linear $\mathrm{ft}$ & 0.37 & 66.73 & & \\
\hline 1 in CPVC Pipe & 25 & linear $\mathrm{ft}$ & 0.57 & 14.33 & & \\
\hline $1 \frac{1}{4}$ in CPVC Pipe & 38 & linear $\mathrm{ft}$ & 0.90 & 34.01 & & \\
\hline 1 1⁄4 in GALV 40 & 10 & linear $\mathrm{ft}$ & 1.57 & 15.70 & & \\
\hline Galvanized Nipples & 1 & each & 5.25 & 5.25 & & \\
\hline 3/4 in CPVC Fitting Tee & 11 & each & 0.69 & 7.59 & & \\
\hline $1 \frac{1 / 4}{4}$ in CPVC Fittings Tee & 1 & each & 2.18 & 2.18 & & \\
\hline 1 in CPVC Red Tee & 6 & each & 1.18 & 7.08 & & \\
\hline $11 / 4$ in CPVC Red Tee & 1 & each & 2.17 & 2.17 & & \\
\hline 3/4 in CPVC 90 Ell & 30 & each & 0.51 & 15.30 & & \\
\hline $1 \frac{1}{1} 4$ in CPVC 90 Ell & 3 & each & 1.44 & 4.32 & & \\
\hline 1 in CPVC Cross & 4 & each & 1.35 & 5.40 & & \\
\hline $1 \frac{1 / 4}{4}$ in CPVC Cross & 1 & each & 1.89 & 1.89 & & \\
\hline 3/4 in CPVC Coupling & 5 & each & 0.50 & 2.48 & & \\
\hline $1 \frac{1 / 4}{4}$ in CPVC Coupling & 3 & each & 0.95 & 2.85 & & \\
\hline $1 \frac{1 / 4}{}$ in CPVC Female Adapter (SL x TH) & 2 & each & 5.31 & 10.62 & & \\
\hline 3/4 in CPVC Caps & 3 & each & 0.30 & 0.90 & & \\
\hline 1 in CPVC Reduced Bushings & 4 & each & 0.39 & 1.54 & & \\
\hline $1 \frac{1 / 4}{4}$ in CPVC Reduced Bushings & 7 & each & 0.60 & 4.21 & & \\
\hline $3 / 4 \times$ X 1/2 in CPVC Female Sprinkler Head Adapter (SLIP x FIPT) & 24 & each & 1.17 & 28.08 & & \\
\hline Galv Fitting Riser & 1 & each & 11.09 & 11.09 & & \\
\hline \multicolumn{7}{|l|}{ Valves } \\
\hline $3 / 4$ in Globe Valve & 1 & each & 5.36 & 5.36 & & \\
\hline $1 \frac{1}{4}$ in Swing Check Valve & 1 & each & 14.12 & 14.12 & & \\
\hline Hose Adapter & 1 & each & 3.12 & 3.12 & & \\
\hline
\end{tabular}


Table 3-8 (continued)

\begin{tabular}{|c|c|c|c|c|c|c|}
\hline $\begin{array}{l}\text { Sprinkler System } \\
\text { Cost Component }\end{array}$ & quantity & units & $\begin{array}{r}\text { bare material } \\
\text { cost per unit }\end{array}$ & $\begin{array}{r}\text { total bare } \\
\text { material cost }\end{array}$ & $\begin{array}{r}\text { labor } \\
\text { cost }\end{array}$ & $\begin{array}{r}\text { combined material } \\
\text { \& labor cost }\end{array}$ \\
\hline \multicolumn{7}{|l|}{ Accessories \& Misc. } \\
\hline $11 / 4$ in Rings & 2 & each & $\$ 0.33$ & $\$ 0.66$ & & \\
\hline 3/8 in Top Beam ATR & 2 & each & 0.35 & 0.70 & & \\
\hline 3/8 in Hole Huggers & 2 & each & 0.31 & 0.62 & & \\
\hline Cement & 1 & each & 11.37 & 11.37 & & \\
\hline $1 \frac{1 / 4}{\text { in Tolcos }}$ & 3 & each & 0.37 & 1.11 & & \\
\hline $3 / 4$ in Tolcos & 43 & each & 0.33 & 14.19 & & \\
\hline 1 in Tolcos & 4 & each & 0.34 & 1.36 & & \\
\hline \multicolumn{7}{|l|}{ Backflow Preventer (BFP) } \\
\hline Flow Switch Tee & 1 & each & 3.43 & 3.43 & & \\
\hline Flow Switch & 1 & each & 62.46 & 62.46 & & \\
\hline Alarm Bell & 1 & each & 29.85 & 29.85 & & \\
\hline PIVS Tamper & 2 & each & 68.03 & 136.06 & & \\
\hline Water Gauge (optional) & 1 & each & 9.87 & 9.87 & & \\
\hline Backflow Preventer Unit & 1 & each & 146.00 & 146.00 & & \\
\hline Total Bare Material Cost without BFP & & & & 406.33 & & \\
\hline Total Bare Material Cost with BFP & & & & 794.00 & & \\
\hline & & & & & & \\
\hline \multicolumn{7}{|l|}{ Labor } \\
\hline Design Cost & & & & & $\$ 332.00$ & \\
\hline Installation Cost without BFP (20 hours at \$ 32 per hour) & & & & & 640.00 & \\
\hline Installation Cost with BFP (22 hours at \$ 32 per hour) & & & & & 704.00 & \\
\hline Total Labor Cost without BFP & & & & & 972.00 & \\
\hline Total Labor Cost with BFP & & & & & 1036.00 & \\
\hline & & & & & & \\
\hline \multicolumn{7}{|l|}{ Totals } \\
\hline Total Materials and Labor Quote without BFP & & & & & & $\$ 1378.33$ \\
\hline Total Materials and Labor Quote with BFP & & & & & & 1830.00 \\
\hline
\end{tabular}


Table 3-9. Cost Summary: Alternative C (Stand-Alone System Using CPVC) for a New $1171 \mathrm{ft}^{2}\left(109 \mathrm{~m}^{2}\right.$ ) Single Family Ranch House

\begin{tabular}{|c|c|c|c|c|c|c|}
\hline $\begin{array}{l}\text { Sprinkler System } \\
\text { Cost Component }\end{array}$ & quantity & units & $\begin{array}{r}\text { bare material } \\
\text { cost per unit }\end{array}$ & $\begin{array}{r}\text { total bare } \\
\text { material cost }\end{array}$ & $\begin{array}{r}\text { labor } \\
\text { cost }\end{array}$ & $\begin{array}{r}\text { combined material } \\
\text { \& labor cost }\end{array}$ \\
\hline \multicolumn{7}{|l|}{ Material } \\
\hline \multicolumn{7}{|l|}{ Fire Sprinklers } \\
\hline LFII $155^{\circ} \mathrm{F}$ White Pendant & 9 & each & $\$ 4.30$ & $\$ 38.70$ & & \\
\hline $1 / 2$ White Esc LFII & 9 & each & 0.70 & 6.30 & & \\
\hline \multicolumn{7}{|l|}{ Pipe \& Fittings } \\
\hline $3 / 4$ in CPVC Pipe & 95 & linear $\mathrm{ft}$ & 0.37 & 35.22 & & \\
\hline 1 in CPVC Pipe & 8 & linear ft & 0.57 & 4.58 & & \\
\hline $11 \frac{1}{4}$ in CPVC Pipe & 5 & linear $\mathrm{ft}$ & 0.90 & 4.48 & & \\
\hline $11 / 4$ in GALV 40 & 10 & each & 1.57 & 15.70 & & \\
\hline Galvanized Nipples & 1 & each & 5.25 & 5.25 & & \\
\hline 3/4 in CPVC Fitting Tee & 5 & each & 0.69 & 3.45 & & \\
\hline $1 \frac{1 / 4}{4}$ CPVC Fittings Tee & 1 & each & 2.18 & 2.18 & & \\
\hline 1 in CPVC Red Tee & 3 & each & 1.18 & 3.54 & & \\
\hline 3/4 in CPVC 90 Ell & 11 & each & 0.51 & 5.61 & & \\
\hline $1 \frac{1 / 4}{4}$ in CPVC 90 Ell & 2 & each & 1.44 & 2.88 & & \\
\hline 3/4 in CPVC Cross & 1 & each & 1.08 & 1.08 & & \\
\hline $3 / 4$ in CPVC Coupling & 5 & each & 0.51 & 2.55 & & \\
\hline 1 in CPVC Coupling & 1 & each & 1.12 & 1.12 & & \\
\hline $1 \frac{1}{4}$ in CPVC Coupling & 2 & each & 1.44 & 2.88 & & \\
\hline $1 \frac{1 / 4}{4}$ in CPVC Female Adapter (SL x TH) & 2 & each & 5.31 & 10.62 & & \\
\hline $3 / 4$ in CPVC Caps & 3 & each & 0.30 & 0.90 & & \\
\hline $1 \frac{1 / 4}{4}$ CPVC Reduced Bushings & 3 & each & 0.60 & 1.80 & & \\
\hline $3 / 4 \times 1 / 2$ in CPVC Female Sprinkler Head Adapter (SLIP x FIPT) & 11 & each & 1.17 & 12.87 & & \\
\hline Galv Fitting Riser & 1 & each & 11.09 & 11.09 & & \\
\hline \multicolumn{7}{|l|}{ Valves } \\
\hline $3 / 4$ in Globe Valve & 1 & each & 5.36 & 5.36 & & \\
\hline $1 \frac{1}{4}$ in Swing Check Valve & 1 & each & 14.12 & 14.12 & & \\
\hline Hose Adapter & 1 & each & 3.12 & 3.12 & & \\
\hline
\end{tabular}


Table 3-9 (continued)

\begin{tabular}{|c|c|c|c|c|c|c|}
\hline $\begin{array}{l}\text { Sprinkler System } \\
\text { Cost Component }\end{array}$ & quantity & units & $\begin{array}{r}\text { bare material } \\
\text { cost per unit }\end{array}$ & $\begin{array}{r}\text { total bare } \\
\text { material cost }\end{array}$ & $\begin{array}{r}\text { labor } \\
\text { cost }\end{array}$ & $\begin{array}{r}\text { combined material } \\
\text { \& labor cost }\end{array}$ \\
\hline \multicolumn{7}{|l|}{ Accessories \& Misc. } \\
\hline $1 \frac{1}{4}$ in Rings & 2 & each & $\$ 0.33$ & $\$ 0.66$ & & \\
\hline 3/8 in Top Beam ATR & 2 & each & 0.35 & 0.70 & & \\
\hline 3/8 in Hole Huggers & 2 & each & 0.31 & 0.62 & & \\
\hline Cement & 1 & each & 11.37 & 11.37 & & \\
\hline $1 \frac{1}{4}$ in Tolcos & 1 & each & 0.37 & 0.37 & & \\
\hline $3 / 4$ in Tolcos & 20 & each & 0.33 & 6.60 & & \\
\hline 1 in Tolcos & 1 & each & 0.34 & 0.34 & & \\
\hline \multicolumn{7}{|l|}{ Backflow Preventer (BFP) } \\
\hline Flow Switch Tee & 1 & each & 3.43 & 3.43 & & \\
\hline Flow Switch & 1 & each & 62.46 & 62.46 & & \\
\hline Alarm Bell & 1 & each & 29.85 & 29.85 & & \\
\hline PIVS Tamper & 2 & each & 68.03 & 136.06 & & \\
\hline Water Gauge (optional) & 1 & each & 18.22 & 18.22 & & \\
\hline Backflow Preventer Unit & 1 & each & 146.00 & 146.00 & & \\
\hline Total Bare Material Cost without BFP & & & & 216.06 & & \\
\hline \multirow[t]{2}{*}{ Total Bare Material Cost with BFP } & & & & 612.08 & & \\
\hline & & & & & & \\
\hline \multicolumn{7}{|l|}{ Labor } \\
\hline Design Cost & & & & & $\$ 235.00$ & \\
\hline Installation Cost without BFP (11 hours at \$ 32 per hour) & & & & & 352.00 & \\
\hline Installation Cost with BFP (13 hours at \$ 32 per hour) & & & & & 416.00 & \\
\hline Total Labor Cost without BFP & & & & & 587.00 & \\
\hline \multirow[t]{2}{*}{ Total Labor Cost with BFP } & & & & & 822.00 & \\
\hline \multirow{2}{*}{\multicolumn{7}{|c|}{ Totals }} \\
\hline & & & & & & \\
\hline Total Materials and Labor Quote without BFP & & & & & & $\$ 803.06$ \\
\hline Total Materials and Labor Quote with BFP & & & & & & 1434.08 \\
\hline & & & & & & \\
\hline
\end{tabular}


Table 3-10. Alternative D (Stand-Alone System Using CPVC) for a New $3338 \mathrm{ft}^{2}\left(310 \mathrm{~m}^{2}\right)$ Single Family Colonial House

\begin{tabular}{|c|c|c|c|c|c|c|}
\hline $\begin{array}{l}\text { Sprinkler System } \\
\text { Cost Component }\end{array}$ & quantity & units & $\begin{array}{r}\text { bare material } \\
\text { cost per unit }\end{array}$ & $\begin{array}{r}\text { total bare } \\
\text { material cost }\end{array}$ & $\begin{array}{r}\text { labor } \\
\text { cost }\end{array}$ & $\begin{array}{r}\text { combined material } \\
\text { \& labor cost }\end{array}$ \\
\hline \multicolumn{7}{|l|}{ Material } \\
\hline \multicolumn{7}{|l|}{ Fire Sprinklers } \\
\hline $16 \mathrm{ft}$ x $16 \mathrm{ft}$ QR Residential & 24 & each & 6.00 & $\$ 144.00$ & & \\
\hline \multicolumn{7}{|l|}{ Pipe and Fittings } \\
\hline Riser Material & 1 & each & $\$ 27.00$ & 27.00 & & \\
\hline $3 / 4$ in CPVC Pipe & 270 & linear $\mathrm{ft}$ & 0.37 & 99.90 & & \\
\hline 1 in CPVC Pipe & 60 & linear $\mathrm{ft}$ & 0.58 & 34.80 & & \\
\hline $11 \frac{1}{4}$ in CPVC Pipe & 40 & linear $\mathrm{ft}$ & 0.90 & 36.00 & & \\
\hline 3/4 in CPVC Coupling & 10 & each & 0.53 & 5.30 & & \\
\hline 1 in CPVC Coupling & 5 & each & 0.68 & 3.40 & & \\
\hline $1 \frac{1 / 4}{4}$ in CPVC Coupling & 2 & each & 1.02 & 2.04 & & \\
\hline 1 in $x$ 3/4 in CPVC Red Bushing & 10 & each & 0.41 & 4.10 & & \\
\hline $1 \frac{1}{4}$ in CPVC Red Bushing & 2 & each & 0.65 & 1.30 & & \\
\hline 1 in to 3/4 in CPVC No Block Hangers/Screws & 24 & each & 0.37 & 8.88 & & \\
\hline 3/4 in to 2 in Double Strap Hangers/Screws & 48 & each & 0.28 & 13.44 & & \\
\hline CPVC Head-Set Brackets/Screws & 24 & each & 0.77 & 18.48 & & \\
\hline Daubers & 10 & each & 0.44 & 4.40 & & \\
\hline 1 1/4 in Grooved Cpl. Adapt. & 1 & each & 7.45 & 7.45 & & \\
\hline 3/4 in CPVC 90 Ell SLXSL & 23 & each & 0.54 & 12.42 & & \\
\hline 1 in CPVC 90 Ell SLXSL & 4 & each & 1.21 & 4.84 & & \\
\hline $11 \frac{1}{4}$ in CPVC 90 Ell SLXSL & 2 & each & 1.51 & 3.02 & & \\
\hline 3/4 in CPVC Tee SLXSLXSL & 13 & each & 0.74 & 9.62 & & \\
\hline 1 in CPVC Tee SLXLSXSL & 6 & each & 1.49 & 8.94 & & \\
\hline $1 \frac{1}{1} 4$ in CPVC Tee SLXSLXSL & 3 & each & 2.35 & 7.05 & & \\
\hline 1 in $x 1$ in $x 3 / 4$ in $x$ 3/4 in CPVC Red Cross & 1 & each & 1.57 & 1.57 & & \\
\hline $3 / 4$ in $x 1 / 2$ in SLX Fipt Head Adapt. & 24 & each & 1.26 & 30.24 & & \\
\hline CSC One Step Cement Pint & 3 & each & 6.01 & 18.03 & & \\
\hline Misc. Pipe Materials & 1 & each & 50.00 & 50.00 & & \\
\hline Thread-Tape per head & 24 & each & 0.32 & 7.68 & & \\
\hline \multicolumn{7}{|l|}{ Valves } \\
\hline $11 / 4$ in Riser Manifold Residential Central & 1 & each & 164.53 & 164.53 & & \\
\hline
\end{tabular}


Table 3-10 (continued)

\begin{tabular}{|c|c|c|c|c|c|c|}
\hline $\begin{array}{l}\text { Sprinkler System } \\
\text { Cost Component }\end{array}$ & quantity & units & $\begin{array}{r}\text { bare material } \\
\text { cost per unit }\end{array}$ & $\begin{array}{r}\text { total bare } \\
\text { material cost }\end{array}$ & $\begin{array}{r}\text { labor } \\
\text { cost }\end{array}$ & $\begin{array}{r}\text { combined material } \\
\& \text { labor cost }\end{array}$ \\
\hline \multicolumn{7}{|l|}{ Backflow Preventer (BFP) } \\
\hline 11/4 in Backflow Preventer Unit w/Ball Valves & 1 & each & $\$ 158.76$ & $\$ 158.76$ & & \\
\hline Total Bare Material Cost without BFP & & & & 70143 & & \\
\hline Total Bare Material Cost with BFP & & & & 860.19 & & \\
\hline \multirow{2}{*}{\multicolumn{7}{|c|}{ Labor }} \\
\hline & & & & & & \\
\hline Design Cost & & & & & $\$ 400.00$ & \\
\hline Installation Cost without BFP (30 hours at $\$ 32.00$ per hour) & & & & & 960.00 & \\
\hline Installation Cost with BFP (32 hours at \$ 32.00 per hour) & & & & & 1024.00 & \\
\hline & & & & & & \\
\hline Total Labor Cost without BFP & & & & & 1360.00 & \\
\hline Total Labor Cost with BFP & & & & & 1424.00 & \\
\hline \multicolumn{7}{|l|}{ 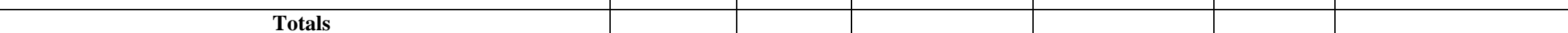 } \\
\hline Total Materials and Labor Quote without BFP & & & & & & $\$ 2061.43$ \\
\hline Total Materials and Labor Quote with BFP & & & & & & 2284.19 \\
\hline & & & & & & \\
\hline
\end{tabular}

Material prices do not include any markup to cover overhead and profit. Three fire sprinklers provided as extras for replacement purposes were removed from the original cost estimate. A fire department connection option was removed from the analysis. 
Table 3-11. Cost Summary: Alternative D (Stand-Alone System Using CPVC) for a New $2257 \mathrm{ft}^{2}$ (210 ${ }^{2}$ ) Single Family Townhouse

\begin{tabular}{|c|c|c|c|c|c|c|}
\hline $\begin{array}{l}\text { Sprinkler System } \\
\text { Cost Component }\end{array}$ & quantity & units & $\begin{array}{r}\text { bare material } \\
\text { cost per unit }\end{array}$ & $\begin{array}{r}\text { total bare } \\
\text { material cost }\end{array}$ & $\begin{array}{r}\text { labor } \\
\text { cost }\end{array}$ & $\begin{array}{r}\text { combined material } \\
\text { \& labor cost }\end{array}$ \\
\hline \multicolumn{7}{|l|}{ Material } \\
\hline \multicolumn{7}{|l|}{ Fire Sprinklers } \\
\hline $16 \mathrm{ft}$ x $16 \mathrm{ft}$ QR Residential & 23 & each & $\$ 6.00$ & $\$ 138.00$ & & \\
\hline \multicolumn{7}{|l|}{ Pipe and Fittings } \\
\hline Riser Material & 1 & each & 27.00 & 27.00 & & \\
\hline 3/4 in CPVC Pipe & 240 & linear $\mathrm{ft}$ & 0.37 & 88.80 & & \\
\hline 1 in CPVC Pipe & 30 & linear $\mathrm{ft}$ & 0.58 & 17.40 & & \\
\hline 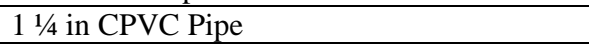 & 40 & linear $\mathrm{ft}$ & 0.90 & 36.00 & & \\
\hline $3 / 4$ in CPVC Coupling & 8 & each & 0.53 & 4.24 & & \\
\hline 1 in CPVC Coupling & 3 & each & 0.68 & 2.04 & & \\
\hline $1 \frac{1}{1 / 4}$ in CPVC Coupling & 2 & each & 1.02 & 2.04 & & \\
\hline 1 in $x^{3 / 4}$ in CPVC Red Bushing & 6 & each & 0.41 & 2.46 & & \\
\hline $1 \frac{1 / 4}{4}$ in $\mathrm{x} 1$ in CPVC Red Bushing & 2 & each & 0.65 & 1.30 & & \\
\hline 1 in to $3 / 4$ in CPVC No Block Hangers/Screws & 23 & each & 0.37 & 8.51 & & \\
\hline $3 / 4$ in to 2 in Double Strap Hangers/Screws & 51 & each & 0.28 & 14.28 & & \\
\hline CPVC Head-Set Brackets/Screws & 23 & each & 0.77 & 17.71 & & \\
\hline Daubers & 10 & each & 0.44 & 4.40 & & \\
\hline $1 \frac{1 / 4}{4}$ in Grooved Cpl. Adapt. & 1 & each & 7.45 & 7.45 & & \\
\hline 3/4 in CPVC 90 Ell SLXSL & 24 & each & 0.54 & 12.96 & & \\
\hline 1 in CPVC 90 Ell SLXSL & 4 & each & 1.21 & 4.84 & & \\
\hline $11 \frac{1 / 4}{4}$ in CPVC 90 Ell SLXSL & 4 & each & 1.51 & 6.04 & & \\
\hline 3/4 in CPVC Tee SLXSLXSL & 7 & each & 0.74 & 5.18 & & \\
\hline 1 in CPVC Tee SLXLSXSL & 8 & each & 1.49 & 11.92 & & \\
\hline 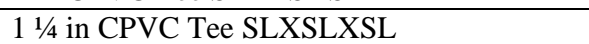 & 8 & each & 2.35 & 18.80 & & \\
\hline $3 / 4$ in X $1 / 2$ in SLX Fipt Head Adapt. & 23 & each & 1.26 & 28.98 & & \\
\hline CSC One Step Cement Pint & 3 & each & 6.01 & 18.03 & & \\
\hline Misc. Pipe Materials & 1 & each & 35.00 & 35.00 & & \\
\hline Thread-Tape per head & 23 & each & 0.32 & 7.36 & & \\
\hline \multicolumn{7}{|l|}{ Valves } \\
\hline $1 \frac{11 / 4 \text { in Riser Manifold Residential Central }}{}$ & 1 & each & 164.53 & 164.53 & & \\
\hline & & & & & & \\
\hline
\end{tabular}


Table 3-11 (continued)

\begin{tabular}{|c|c|c|c|c|c|c|}
\hline $\begin{array}{l}\text { Sprinkler System } \\
\text { Cost Component }\end{array}$ & quantity & units & $\begin{array}{r}\text { bare material } \\
\text { cost per unit }\end{array}$ & $\begin{array}{r}\text { total bare } \\
\text { material cost }\end{array}$ & $\begin{array}{r}\text { labor } \\
\text { cost }\end{array}$ & $\begin{array}{r}\text { combined material } \\
\text { \& labor cost }\end{array}$ \\
\hline \multicolumn{7}{|l|}{ Backflow Preventer (BFP) } \\
\hline 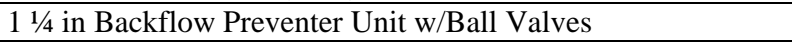 & 1 & each & $\$ 158.76$ & $\$ 158.76$ & & \\
\hline Total Bare Material Cost without BFP & & & & 685.27 & & \\
\hline Total Bare Material Cost with BFP & & & & 844.03 & & \\
\hline \multicolumn{7}{|l|}{ Labor } \\
\hline Design Cost & & & & & $\$ 290.00$ & \\
\hline Installation Cost without BFP (23.7 hours at \$ 32.00 per hour) & & & & & 685.27 & \\
\hline Installation Cost with BFP (25.7 hours at \$ 32.00 per hour) & & & & & 844.03 & \\
\hline & & & & & & \\
\hline Total Labor Cost without BFP & & & & & 1048.40 & \\
\hline Total Labor Cost with BFP & & & & & 1112.40 & \\
\hline \multicolumn{7}{|l|}{ Totals } \\
\hline Total Materials and Labor Quote without BFP & & & & & & $\$ 1733.67$ \\
\hline Total Materials and Labor Quote with BFP & & & & & & 1956.43 \\
\hline
\end{tabular}

Three fire sprinklers provided as extras for replacement purposes were removed from the original cost estimate. Material prices do not include any markup to cover overhead and profit. A fire department connection option was removed from the analysis. 
Table 3-12. Cost Summary: Alternative D (Stand-Alone System Using CPVC) for a New $1171 \mathrm{ft}^{2}\left(109 \mathrm{~m}^{2}\right)$ Single Family Ranch House

\begin{tabular}{|c|c|c|c|c|c|c|}
\hline $\begin{array}{l}\text { Sprinkler System } \\
\text { Cost Component }\end{array}$ & quantity & units & $\begin{array}{r}\text { bare material } \\
\text { cost per unit }\end{array}$ & $\begin{array}{r}\text { total bare } \\
\text { material cost }\end{array}$ & $\begin{array}{r}\text { labor } \\
\text { cost }\end{array}$ & $\begin{array}{r}\text { combined material } \\
\& \text { labor cost }\end{array}$ \\
\hline \multicolumn{7}{|l|}{ Material } \\
\hline \multicolumn{7}{|l|}{ Fire Sprinklers } \\
\hline $16 \mathrm{ft}$ x $16 \mathrm{ft}$ QR Residential & 10 & each & $\$ 6.00$ & $\$ 60.00$ & & \\
\hline \multirow{2}{*}{\multicolumn{7}{|c|}{ Pipe and Fittings }} \\
\hline Riser Material & 1 & each & 27.00 & 2700 & & \\
\hline $3 / 4$ in CPVC Pipe & 120 & each & 0.37 & 44.40 & & \\
\hline 1 in CPVC Pipe & 15 & each & 0.58 & 8.70 & & \\
\hline 3/4 in CPVC Coupling & 4 & each & 0.53 & 2.12 & & \\
\hline 1 in CPVC Coupling & 1 & each & 0.68 & 0.68 & & \\
\hline 1 in $\mathrm{x} 3 / 4$ in CPVC Red Bushing & 2 & each & 0.41 & 0.82 & & \\
\hline 1 in Female SL x TH Female Adapter & 1 & each & 3.22 & 3.22 & & \\
\hline 1 in to $3 / 4$ in CPVC No Block Hangers/Screws & 10 & each & 0.37 & 3.70 & & \\
\hline 3/4 in to 2 in Double Strap Hangers/Screws & 19 & each & 0.28 & 5.32 & & \\
\hline CPVC Head-Set Brackets/Screws & 10 & each & 0.77 & 7.70 & & \\
\hline Daubers & 2 & each & 0.44 & 0.88 & & \\
\hline 3/4 in CPVC 90 Ell SLXSL & 9 & each & 0.54 & 4.86 & & \\
\hline 1 in CPVC 90 Ell SLXSL & 1 & each & 1.21 & 1.21 & & \\
\hline 3/4 in CPVC Tee SLXSLXSL & 5 & each & 0.74 & 3.70 & & \\
\hline 1 in CPVC Tee SLXLSXSL & 1 & each & 1.49 & 1.49 & & \\
\hline $3 / 4$ in $X 1 / 2$ in SLX Fipt Head Adapt. & 10 & each & 1.26 & 12.60 & & \\
\hline CSC One Step Cement Pint & 2 & each & 6.01 & 12.02 & & \\
\hline Misc. Pipe Materials & 1 & each & 25.00 & 25.00 & & \\
\hline Thread-Tape per head & 10 & each & 0.32 & 3.20 & & \\
\hline \multirow{2}{*}{\multicolumn{7}{|c|}{ Valves }} \\
\hline & & & & & & \\
\hline 1 in Riser Manifold Residential Central & 1 & each & 135.00 & 135.00 & & \\
\hline \multicolumn{7}{|l|}{ Backflow Preventer (BFP)s } \\
\hline 1 in Backflow Preventer Unit w/Ball Valves & 1 & each & 125.00 & 125.00 & & \\
\hline Total Bare Material Cost without BFP & & & & 363.62 & & \\
\hline Total Bare Material Cost with BFP & & & & 488.62 & & \\
\hline & & & & & & \\
\hline
\end{tabular}


Table 3-12 (continued)

\begin{tabular}{|c|c|c|c|c|c|c|}
\hline $\begin{array}{l}\text { Sprinkler System } \\
\text { Cost Component }\end{array}$ & quantity & units & $\begin{array}{r}\text { bare material } \\
\text { cost per unit }\end{array}$ & $\begin{array}{r}\text { total bare } \\
\text { material cost }\end{array}$ & $\begin{array}{r}\text { labor } \\
\text { cost }\end{array}$ & $\begin{array}{r}\text { combined material } \\
\text { \& labor cost }\end{array}$ \\
\hline \multicolumn{7}{|l|}{ Labor } \\
\hline Design Cost & & & & & $\$ 179.00$ & \\
\hline Installation Cost without BFP (13 hours at \$ 32.00 per hour) & & & & & 416.00 & \\
\hline Installation Cost with BFP (15 hours at \$ 32.00 per hour) & & & & & 480.00 & \\
\hline Total Labor Cost without BFP & & & & & 595.00 & \\
\hline Total Labor Cost with BFP & & & & & 659.00 & \\
\hline \multirow{2}{*}{\multicolumn{7}{|c|}{$\begin{array}{c}\text { Totals } \\
\end{array}$}} \\
\hline & & & & & & \\
\hline Total Materials and Labor Quote without BFP & & & & & & $\$ 958.62$ \\
\hline Total Materials and Labor Quote with BFP & & & & & & 1147.62 \\
\hline & & & & & & \\
\hline
\end{tabular}

Three fire sprinklers provided as extras for replacement purposes were removed from the original cost estimate. Material prices do not include any markup to cover overhead and profit. A fire department connection option was removed from the analysis. 


\subsection{Markup and Inspection Cost Information}

Table 3-13 summarizes the results of the previous section, by sprinkler alternative and house type. The table shows the bare material cost, before markups and inspection, combined with the estimated design and installation cost.

Table 3-13: Cost Estimate Summary Table, Before Markups and Inspection

\begin{tabular}{|c|c|c|c|c|c|c|}
\hline House & \multicolumn{6}{|c|}{ Sprinkler Alternative } \\
\hline Type & A & $\mathrm{B}$ & C no BFP & $\mathrm{C}$ w/ BFP & D no BFP & D w/ BFP \\
\hline Colonial & $\$ 1419.78$ & $\$ 1515.00$ & $\$ 1429.60$ & $\$ 1881.27$ & $\$ 2061.43$ & $\$ 2284.19$ \\
\hline Townhouse & 1301.38 & 1380.00 & 1378.33 & 1830.00 & 1733.67 & 1956.43 \\
\hline Ranch & 601.16 & 784.00 & 803.06 & 1434.08 & 958.62 & 1147.62 \\
\hline
\end{tabular}

Table 3-13 does not report the total sprinkler system cost to the homeowner because the dollar amounts do not include a markup on materials or-for Alternatives $C$ and D with BFP - the present value of inspection costs. Subsequent tables present costs with material markups and inspection costs. Material markup was not standardized in Tables 3-1 through 3-12 due to the fact that material markup can vary across alternatives - in other words, Alternative A might have a higher material markup than Alternative B. Choosing different material markups affects the cost-effectiveness of the alternatives, and the effect is magnified in alternatives where the cost of material makes up a large portion of total costs. Tables 3-14 through 3-18 provide cost estimations assuming markups of $10 \%$, $20 \%, 30 \%, 50 \%$ and $100 \%{ }^{14}$

\footnotetext{
${ }^{14}$ These percentages are based on markup data obtained from fire sprinkler system manufacturers and installers including those contributing to this study.
} 
Table 3-14: Cost Estimate Summary Table at $10 \%$ Material Markup

\begin{tabular}{|l|r|r|r|r|r|r|}
\hline \multicolumn{1}{|c|}{$\begin{array}{c}\text { House } \\
\text { Type }\end{array}$} & \multicolumn{1}{|c|}{ A } & \multicolumn{1}{c|}{ B } & \multicolumn{1}{c|}{ C no BFP } & \multicolumn{1}{c|}{ C w/ BFP } & \multicolumn{1}{c|}{ D no BFP } & \multicolumn{1}{c|}{ w/ BFP } \\
\hline Colonial & $\$ 1510.56$ & $\$ 1559.29$ & $\$ 1475.96$ & $\$ 1966.40$ & $\$ 2131.57$ & $\$ 2370.21$ \\
\hline Townhouse & 1383.52 & 1416.76 & 1418.96 & 1909.40 & 1802.20 & 2040.83 \\
\hline Ranch & 635.68 & 800.85 & 824.67 & 1495.29 & 994.98 & 1196.48 \\
\hline
\end{tabular}

Table 3-15: Cost Estimate Summary Table at 20 \% Material Markup

\begin{tabular}{|l|r|r|r|r|r|r|}
\hline \multicolumn{1}{|c|}{$\begin{array}{c}\text { House } \\
\text { Type }\end{array}$} & \multicolumn{1}{|c|}{ A } & \multicolumn{1}{c|}{ B } & \multicolumn{1}{c|}{ C no BFP } & \multicolumn{1}{c|}{ C w/ BFP } & \multicolumn{1}{c|}{ D no BFP } & \multicolumn{1}{c|}{ D BFP } \\
\hline Colonial & $\$ 1601.34$ & $\$ 1603.59$ & $\$ 1522.32$ & $\$ 2051.52$ & $\$ 2201.72$ & $\$ 2456.23$ \\
\hline Townhouse & 1465.66 & 1453.92 & 1459.60 & 1988.80 & 1870.72 & 2125.24 \\
\hline Ranch & 670.19 & 817.38 & 846.27 & 1556.50 & 1031.34 & 1245.34 \\
\hline
\end{tabular}

Table 3-16: Cost Estimate Summary Table at 30 \% Material Markup

\begin{tabular}{|l|r|r|r|r|r|r|}
\hline \multicolumn{1}{|c|}{$\begin{array}{c}\text { House } \\
\text { Type }\end{array}$} & \multicolumn{1}{|c|}{ A } & \multicolumn{1}{c|}{ B } & \multicolumn{1}{c|}{ C no BFP } & \multicolumn{1}{c|}{ C w/ BFP } & \multicolumn{1}{c|}{ D no BFP } & \multicolumn{1}{c|}{ D w BFP } \\
\hline Colonial & $\$ 1692.11$ & $\$ 1647.89$ & $\$ 1568.68$ & $\$ 2136.65$ & $\$ 2271.86$ & $\$ 2542.25$ \\
\hline Townhouse & 1547.79 & 1491.08 & 1500.23 & 2068.20 & 1939.25 & 2209.64 \\
\hline Ranch & 704.71 & 833.92 & 867.88 & 1617.70 & 1067.71 & 1294.21 \\
\hline
\end{tabular}

Table 3-17: Cost Estimate Summary Table at 50 \% Material Markup

\begin{tabular}{|l|r|r|r|r|r|r|}
\hline \multicolumn{1}{c|}{$\begin{array}{c}\text { House } \\
\text { Type }\end{array}$} & \multicolumn{1}{|c|}{ A } & \multicolumn{1}{c|}{ B } & \multicolumn{1}{c|}{ C no BFP } & \multicolumn{1}{c|}{ C w/ BFP } & \multicolumn{1}{c|}{ D no BFP } & \multicolumn{1}{c|}{ D w BFP } \\
\hline Colonial & $\$ 1873.67$ & $\$ 1736.49$ & $\$ 1661.40$ & $\$ 2306.91$ & $\$ 2412.15$ & $\$ 2714.29$ \\
\hline Townhouse & 1712.07 & 1565.40 & 1581.50 & 2227.00 & 2076.31 & 2378.45 \\
\hline Ranch & 773.74 & 866.98 & 911.09 & 1740.12 & 1140.43 & 1391.93 \\
\hline
\end{tabular}

Table 3-18: Cost Estimate Summary Table at $100 \%$ Material Markup

\begin{tabular}{|l|r|r|r|r|r|r|}
\hline \multicolumn{1}{|c|}{$\begin{array}{c}\text { House } \\
\text { Type }\end{array}$} & \multicolumn{1}{|c|}{ A } & \multicolumn{1}{c|}{ B } & \multicolumn{1}{c|}{ C no BFP } & \multicolumn{1}{c|}{ C w/ BFP } & \multicolumn{1}{c|}{ D no BFP } & \multicolumn{1}{c|}{ D $/$ BFP } \\
\hline Colonial & $\$ 2327.56$ & $\$ 1957.98$ & $\$ 1893.20$ & $\$ 2732.54$ & $\$ 2762.86$ & $\$ 3144.38$ \\
\hline Townhouse & 2122.76 & 1751.20 & 1784.66 & 2624.00 & 2418.94 & 2800.46 \\
\hline Ranch & 946.32 & 949.64 & 1019.12 & 2046.16 & 1322.24 & 1636.24 \\
\hline
\end{tabular}


In addition to material markup, the present value of annual inspection costs should be added to Alternatives $\mathrm{C}$ and $\mathrm{D}$ when they include the optional backflow preventer. The present value calculation is made according to Equation 2-5, a Uniform Present-Value (UPV) Equation which discounts a series of payments to the equivalent present value.

Inspection costs are provided to comply with the maintenance recommended by backflow prevention device manufacturers. For example, the owner's manuals for a major manufacturer of backflow prevention devices recommend annual inspections to check that seals are holding against flow. The test procedure requires specific tools and instruments and cannot be performed by the typical homeowner.

In order to calculate present value, the study period and discount rate must be specified. The 2003 American Housing Survey reports the median tenure of homeowners is 9 years, and is used in this report. The real, after-tax annual rate of return in large-cap stocks over the period 1925 to 2005, obtained from Ibbotson Associates (2005), is $4.8 \%$, and the average yield rate for municipal bonds over the period 1919 to 2004 is $1.3 \%$. These rates of return are used as lower and upper bounds discount rates in this report.

Tables 3-19 and 3-20 present a range of present value costs for \$ 100 and \$ 200 annual inspection fees.

Table 3-19: Present Value of \$ 100 Inspection by Study Period and Discount Rate

\begin{tabular}{|c|c|c|c|c|c|c|}
\hline \multirow[t]{2}{*}{ Rate } & \multicolumn{6}{|c|}{$\begin{array}{l}\text { Study period } \\
\text { (median } \\
\text { tenure) }\end{array}$} \\
\hline & 1 & 5 & 9 & 10 & 15 & 30 \\
\hline $1.3 \%$ & $\$ 98.72$ & $\$ 481.08$ & $\$ 844.18$ & $\$ 932.07$ & $\$ 1354.85$ & $\$ 2471.07$ \\
\hline $4.8 \%$ & 95.42 & 435.35 & 717.16 & 779.73 & 1052.14 & 1572.92 \\
\hline
\end{tabular}

Table 3-20: Present Value of \$ 200 Inspection by Study Period and Discount Rate

\begin{tabular}{|c|c|c|c|c|c|c|}
\hline \multirow[t]{2}{*}{ Rate } & \multicolumn{6}{|c|}{$\begin{array}{l}\text { Study period } \\
\text { (median } \\
\text { tenure) }\end{array}$} \\
\hline & 1 & 5 & 9 & 10 & 15 & 30 \\
\hline $1.3 \%$ & $\$ 197.43$ & $\$ 962.15$ & \$ 1688.37 & $\$ 1864.13$ & $\$ 2709.70$ & $\$ 4942.14$ \\
\hline $4.8 \%$ & 190.84 & 870.70 & 1434.31 & 1559.46 & 2104.28 & 3145.84 \\
\hline
\end{tabular}

These inspection cost estimates are added to the cost of Alternative C and D with backflow preventers.

\subsection{Life-Cycle Cost Comparison Summary}

The comparative analysis is applied to the cost data to determine which of the proposed sprinkler systems has the lowest estimated life-cycle cost in each house type. Estimated cost results for all systems are within a close range. Their cost-effectiveness is dependent upon the decision to incorporate a backflow preventer in a stand-alone system and the markup on materials.

When material markups are constrained to the same value across all Alternatives, and BFP are not required: Alternative $\mathrm{C}$ is least cost for the Colonial for all markups; Alternative $\mathrm{A}$ is least cost for 
the Townhouse at a $10 \%$ markup, while Alternative B is least cost for the Townhouse at higher markups; and Alternative A is least cost for the Ranch for all markups. ${ }^{15}$

When different markups are applied to materials, results can shift. For example, if Alternative A has a $100 \%$ markup, and all the other Alternatives have $20 \%$ markups, then the least-cost choice for the Ranch is Alternative B. ${ }^{16}$

Alternatives B and C without BFP have lower LCC than Alternative D without BFP. The higher price of Alternative $\mathrm{D}$ is due to a higher number of installation hours and more materials costs. For example, Alternative D (without BFP) installed in a Colonial house required an estimated 30 hours of installation labor, whereas Alternatives B and C (without BFP) installed in a Colonial house required an estimated 20 and 21 hours. The higher installation cost accounts for roughly half of the cost difference between Alternative D (without BFP) and Alternatives B and C (without BFP), before material markups are added.

When material markups are constrained to the same value across all Alternatives, and BFP are required in stand-alone systems, Alternative A is least cost for all house types. This result is due to the recurring expense of having the BFP professionally inspected every year. In this report, Alternative A does not have any distinct, quantifiable recurring expenses. ${ }^{17}$

In the Colonial and Townhouse, Alternative $\mathrm{C}$ with BFP can be least-cost when compared to Alternative A under certain conditions. In the Colonial, when Alternative A is marked up $100 \%$ and Alternative $\mathrm{C}$ with BFP is marked up $50 \%$ or less, Alternative $\mathrm{C}$ with BFP is least-cost, when the cost of an annual inspection is not included. In the Colonial, when a \$100 annual inspection is included, Alternative $\mathrm{C}$ with BFP is least-cost when it is marked up $10 \%$ or less, homeowner tenure is significantly less than 5 years, and the discount rate is significantly higher than $4.8 \%$.

In the Townhouse, when Alternative A is marked up $100 \%$ and Alternative $C$ with BFP is marked up $30 \%$ or less, Alternative $\mathrm{C}$ with BFP is least-cost, when the cost of an annual inspection is not included. In the Townhouse, when a \$ 100 annual inspection is included, Alternative C with BFP is least-cost when it is marked up $10 \%$ or less, homeowner tenure is significantly less than 5 years, and the discount rate is significantly higher than $4.8 \%$.

\footnotetext{
${ }^{15}$ These conclusions are drawn from the results shown in Tables 3-14 through 3-18.

${ }^{16}$ The cost of Alternative A (\$946.32, from Table 3-18) was compared with the cost of Alternative B (\$817.38, from Table 3-15). This example assumes that the homeowner would pay a different markup depending on Alternative.

${ }^{17}$ This conclusion is drawn from combining the results shown in Tables 3-14 through 3-18 with a chosen present value selected from Table 3-19 or 3-20. When BFP are required, only Alternatives A, C (with BFP) and D (with BFP) may be compared. The present value of the cost of inspection must be added to the cost of Alternative C (with BFP) and D (with BFP).
} 


\section{Summary and Suggestions for Future Research}

\subsection{Summary}

This report has developed a life-cycle cost model consistent with ASTM E917-02 and applied it to data developed by the Building and Fire Research Laboratory (BFRL) to select the least-cost residential sprinkler system in each of three house types, using cost estimates provided by manufacturers and installers of residential sprinkler systems. Data are developed and presented in this report to support the cost comparison methodology.

The comparative analysis is applied to the cost data to determine which of the proposed systems has the lowest estimated life-cycle cost in each house type. Estimated cost results for all systems are within a close range, and are dependent upon the decision to incorporate a backflow preventer in a stand-alone system and the material markup.

Table 4-1 summarizes the results found in Chapter 3.

Table 4-1. Least-Cost Sprinkler Alternatives by House type

\begin{tabular}{|r|c|c|}
\hline \multirow{2}{*}{ House Type } & \multicolumn{2}{|c|}{$\begin{array}{c}\text { Least-Cost Installation } \\
\text { with backflow preventer }\end{array}$} \\
\hline Colonial & $\mathrm{C}$ & A or C $^{2}$ \\
\hline Townhouse & $\mathrm{B}^{1}$ & A or C \\
\hline Ranch & $\mathrm{A}$ & $\mathrm{A}$ \\
\hline $\begin{array}{l}{ }^{1} \mathrm{~A} \text { is least-cost when markups are uniform across all Alternatives and set below } 20 \% . \\
{ }^{2} \text { Section 3.5 explains the circumstances under which Alternative C is least-cost. }\end{array}$ \\
\hline
\end{tabular}

Table 4-1 indicates that stand-alone sprinkler designs (C and B) are least-cost in the Colonial and Townhouse, when backflow preventers are not included. When backflow preventers are included in the Colonial and Townhouse, a stand alone system (C) can be least-cost when annual backflow inspection costs are low, homeowner tenure is short, and discount rates are high. When annual inspection costs are higher, homeowner tenure is longer, or discount rates are low, then the multipurpose network system (A) is least-cost. The multipurpose network system (A) is least-cost in the Ranch whether backflow preventers are included or not.

\subsection{Suggestions for Future Research}

The least-cost sprinkler systems identified in this report will form the basis for a follow-on benefitcost study. That study will develop estimates of all benefits and will expand the cost data to include an estimate of operating cost. Operating costs include water cost and water damage cost, incurred only if the system activates accidentally when there is no fire. The follow-on report will estimate the cost effectiveness of sprinkler systems. 



\section{References}

ASTM International. "Standard Practice for Measuring Life-Cycle Costs of Buildings and Building Systems,” E 917-02, Annual book of ASTM Standards: 2002. West Conshohoken, PA, ASTM International.

NFPA International, "Standard for the Installation of Sprinkler Systems in One and Two Family Dwellings and Manufactured Homes 2002 Edition,” NFPA 13D, National Fire Protection Association, 2002.

NFPA International, "Standard for the Inspection, Testing, and Maintenance of Water-Based Fire Protection Systems, 2002 edition,” NFPA 25, National Fire Protection Association, 2002.

Siarnicki, Ronald Jon, Residential Sprinklers: One Community's Experience Twelve Years After Mandatory Implementation. Jan. 2001.

Ibbotson Associates, “Stocks, Bonds, and Bills after Taxes and Inflation: Year-end 1925-2004,” PM006 (2005).

U.S. Census Bureau, Current Housing Reports, Series H150/03, American Housing Survey for the United States: 2003. U.S. Government Printing Office, Washington, DC. 



\section{Appendix A \\ Prototypical Houses}

The NIST-designed prototypical houses were developed to form a physical basis for cost estimations. They do not represent a recommended sprinkler system design.

Figure A-1. Prototypical Colonial House: Basement Floorplan

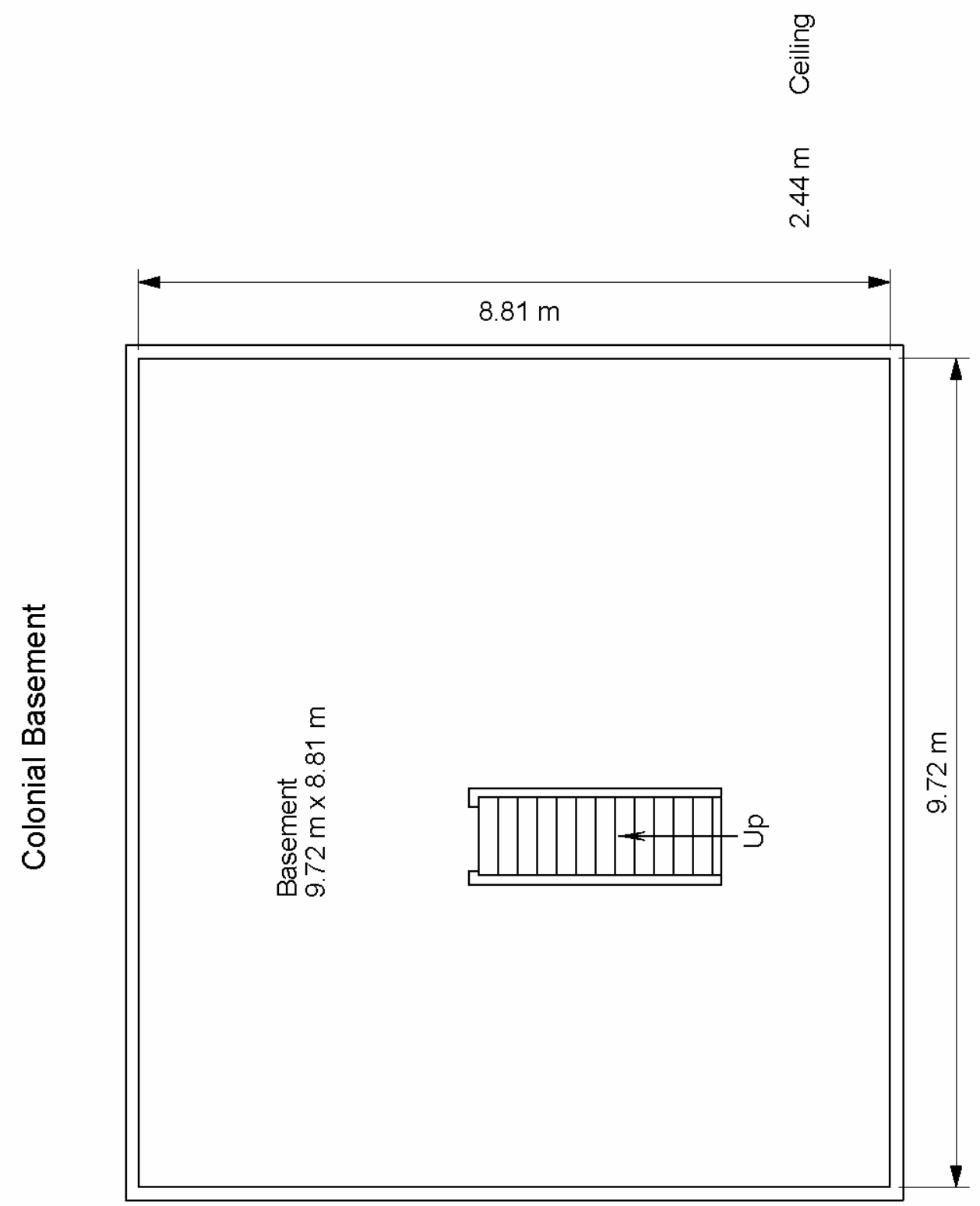


Figure A-2. Prototypical Colonial House: 1st Floor Floorplan

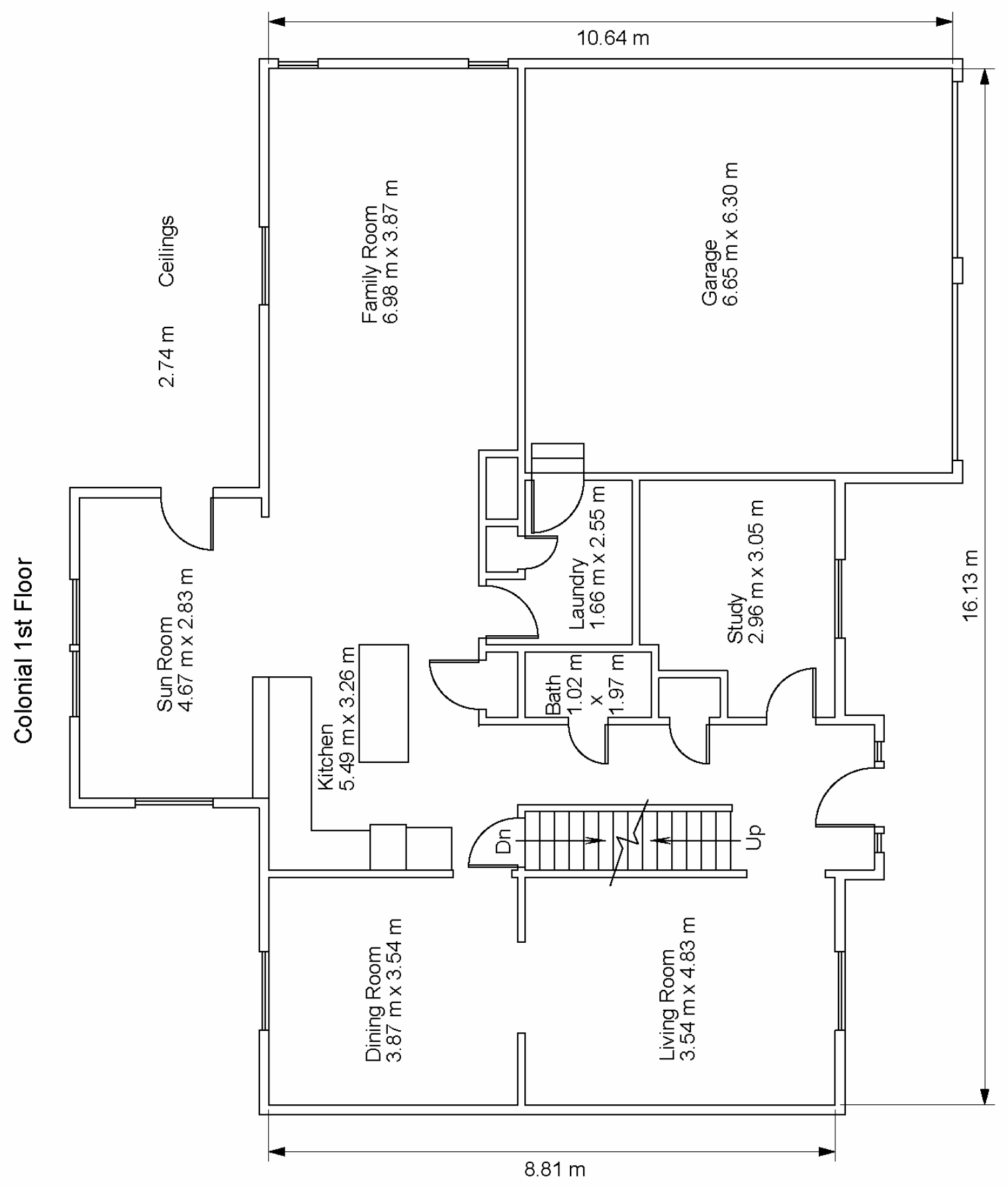


Figure A-3. Prototypical Colonial House: 2nd Floor Floorplan

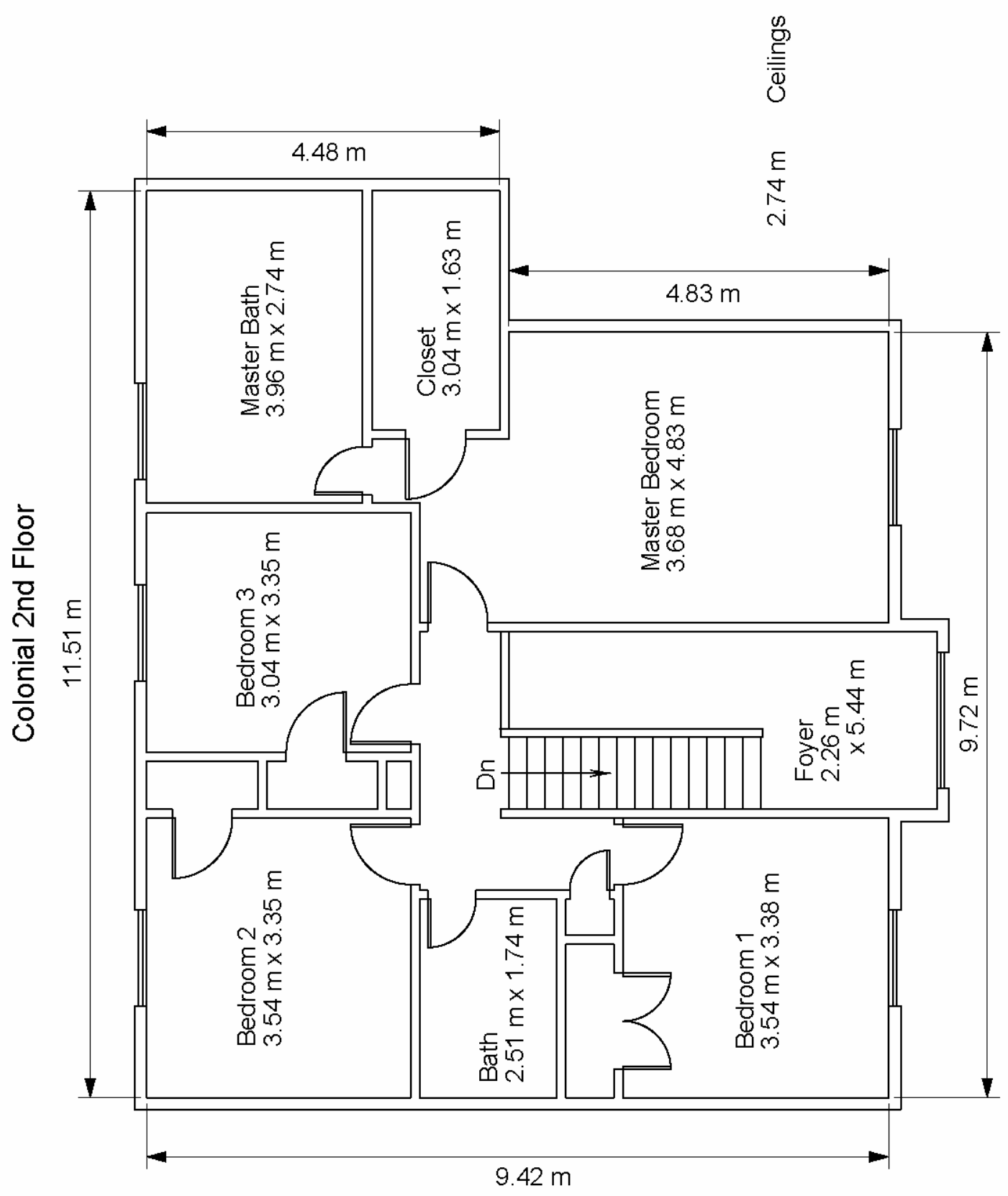


Figure A-4. Prototypical Townhouse Floorplans
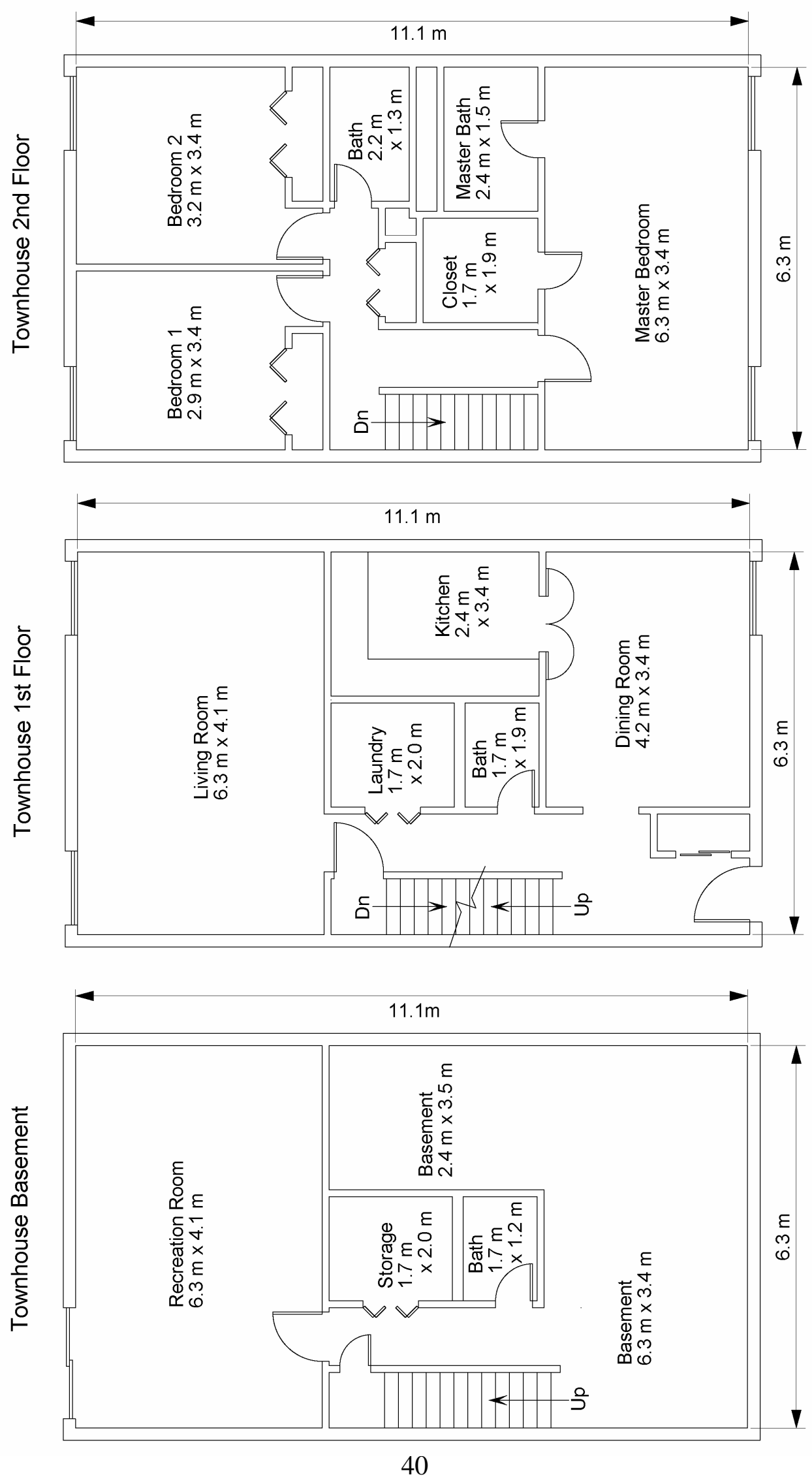
Figure A-5. Prototypical Ranch Floorplan

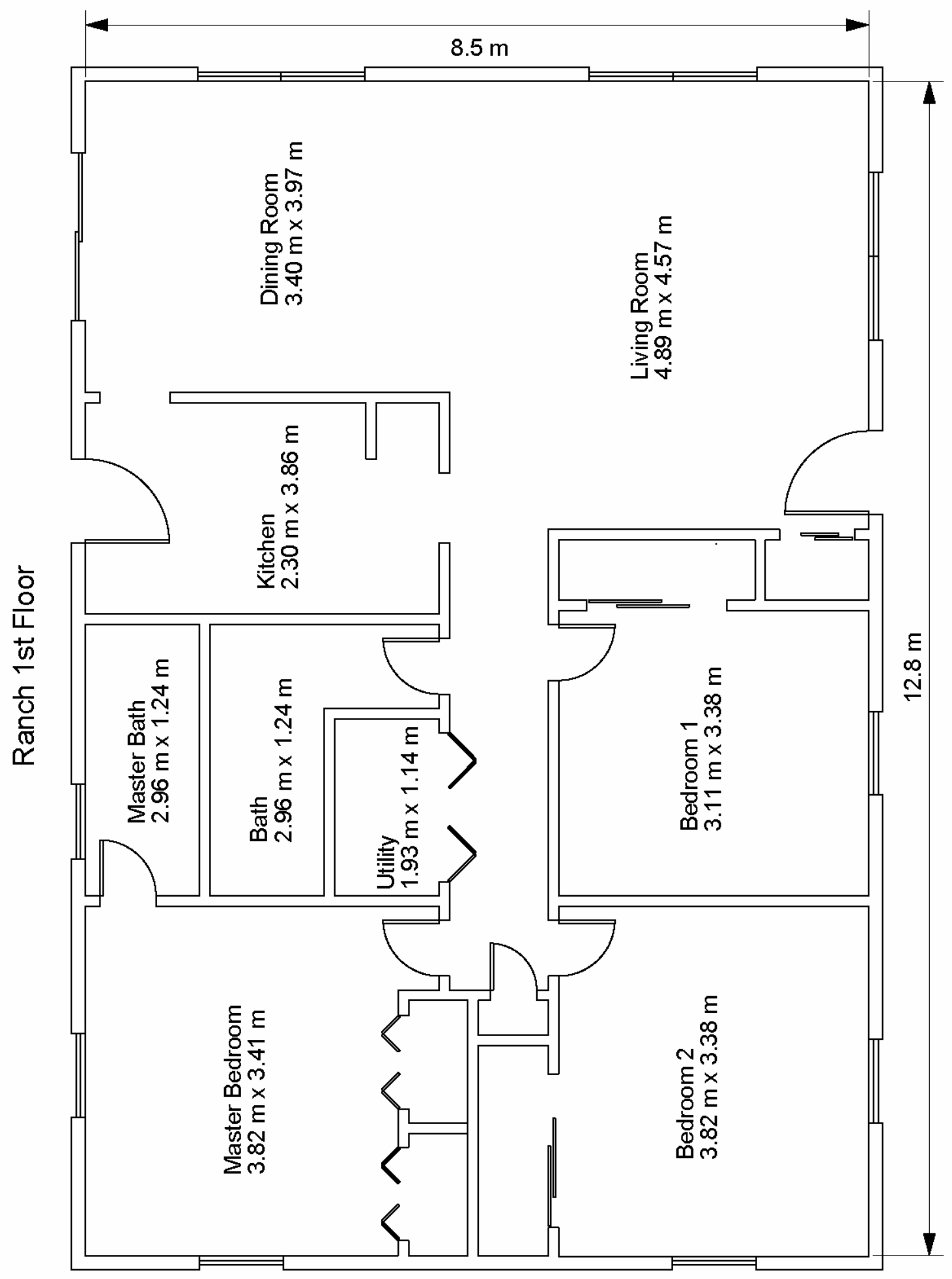





\section{Appendix B \\ Stand-Alone Fire Sprinkler Installation Plan}

The sprinkler system systems shown in this Appendix come from Pete Schwab of Wayne Automatic Fire Sprinkler. The floorplans are presented in customary units and are reproduced as they were received.

Figure B-1. Stand-Alone Fire Sprinkler Installation in Colonial House Basement

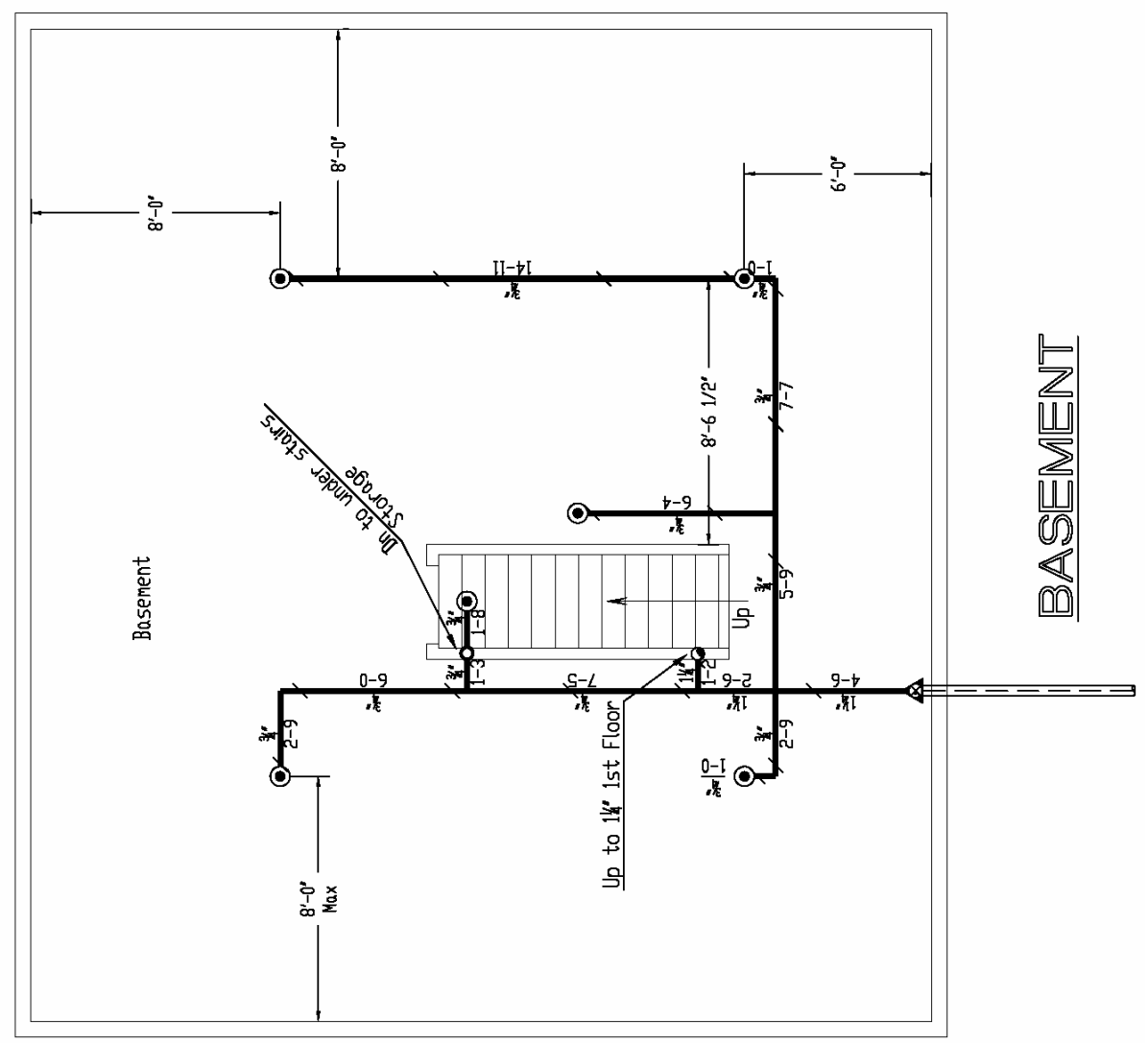


Figure B-2. Stand-Alone Fire Sprinkler Installation in Colonial House 1st Floor

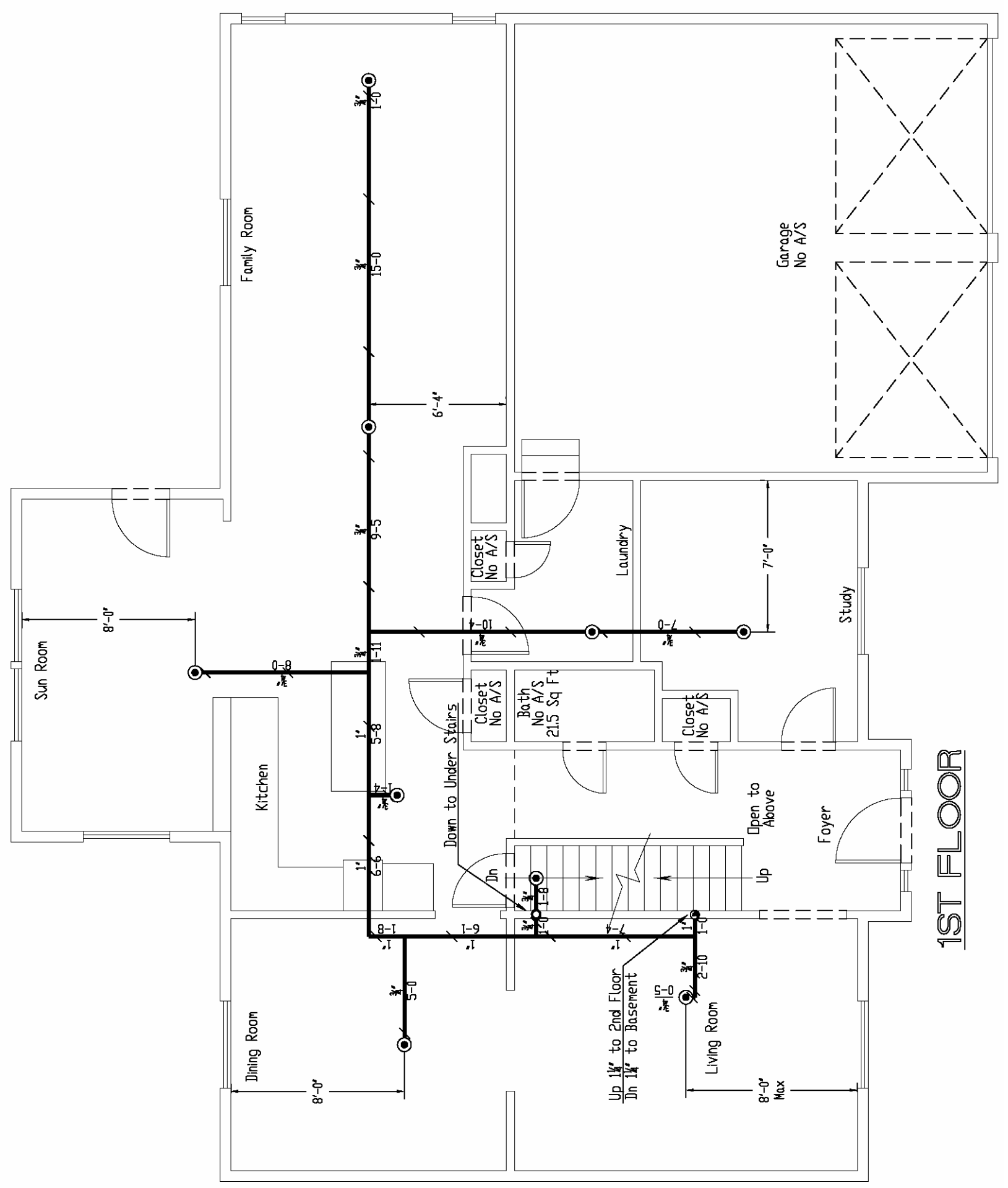


Figure B-3. Stand-Alone Fire Sprinkler Installation in Colonial House 2nd Floor

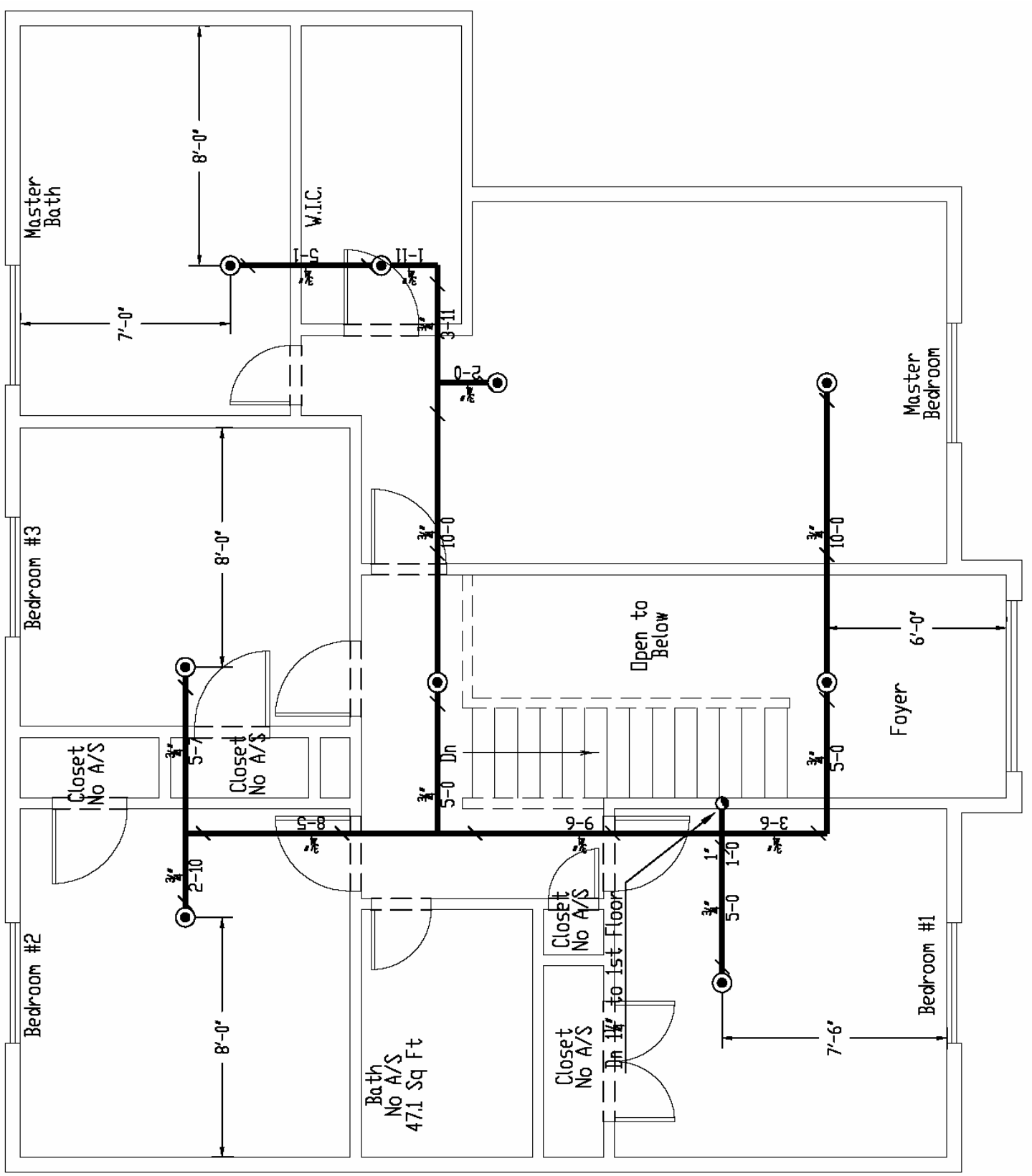

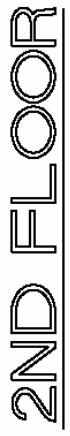


Figure B-4. Stand-Alone Fire Sprinkler Installation in Townhouse Basement

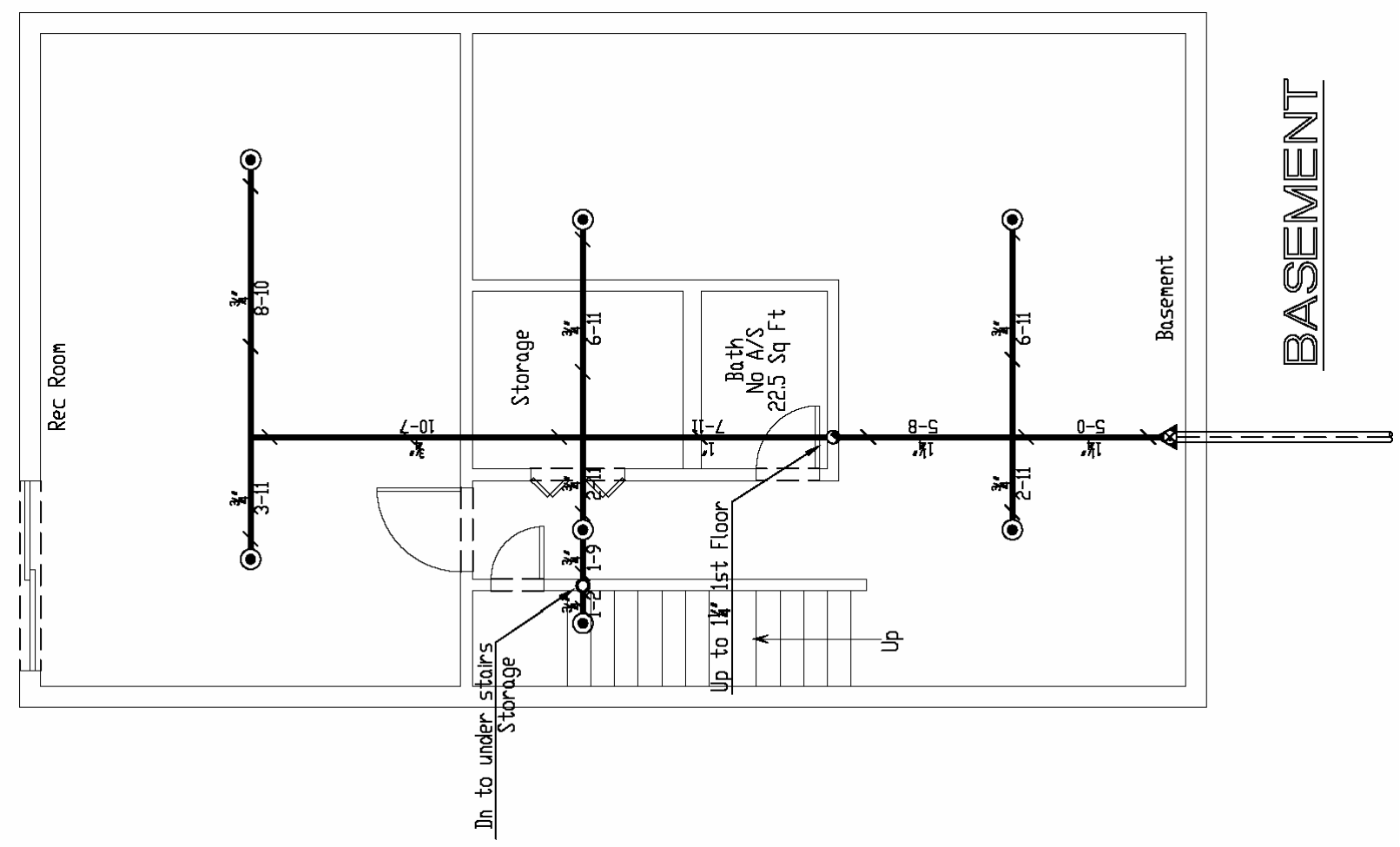


Figure B-5. Stand-Alone Fire Sprinkler Installation in Townhouse 1st \& 2nd Floors

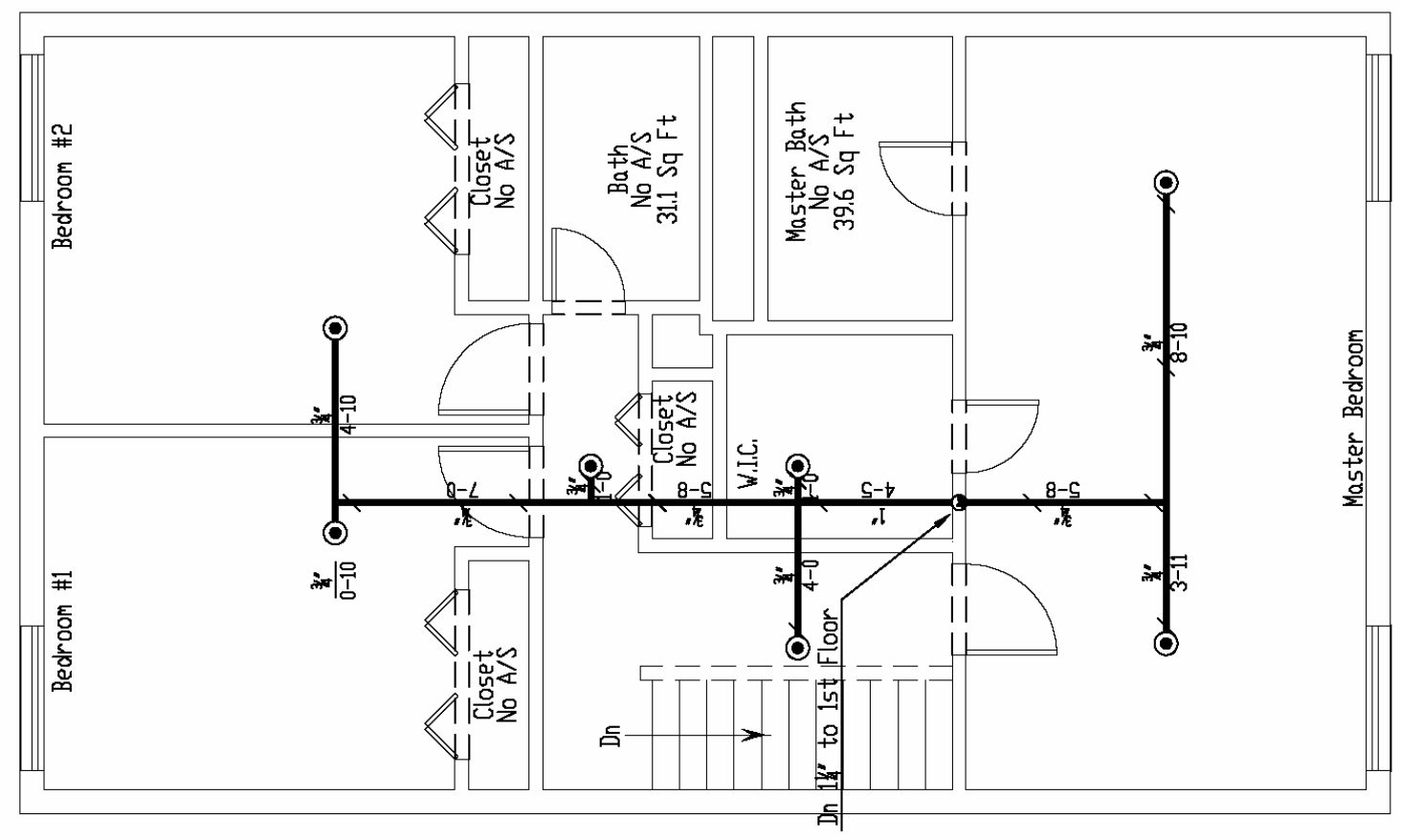

$\mathbb{a}$
$\square$
$\mathbb{1}$
$\mathbb{\mathbb { Z }}$
$\mathbb{\mathbb { N }}$

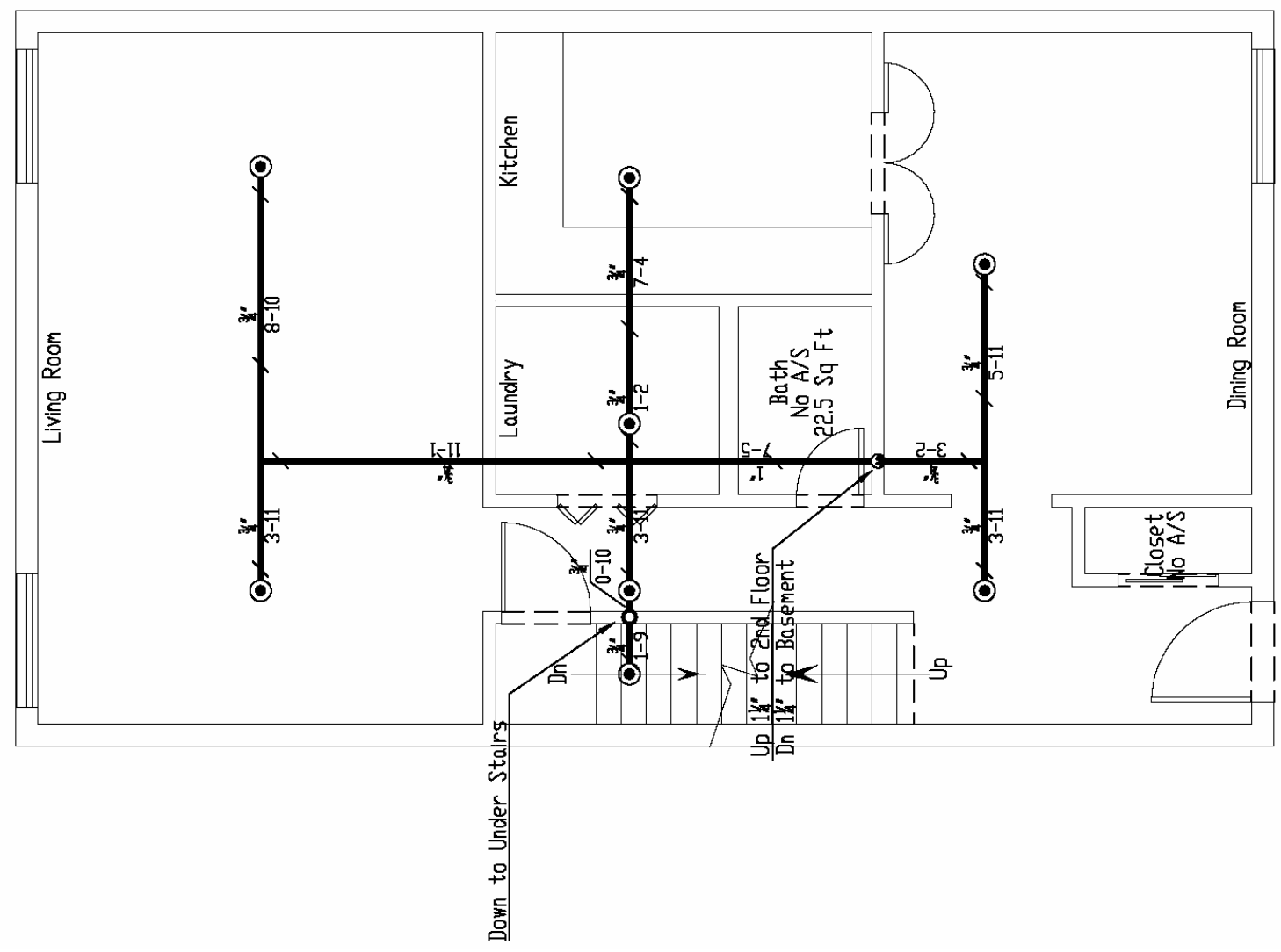

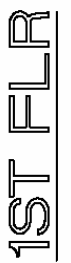


Figure B-6. Stand-Alone Fire Sprinkler Installation in Ranch

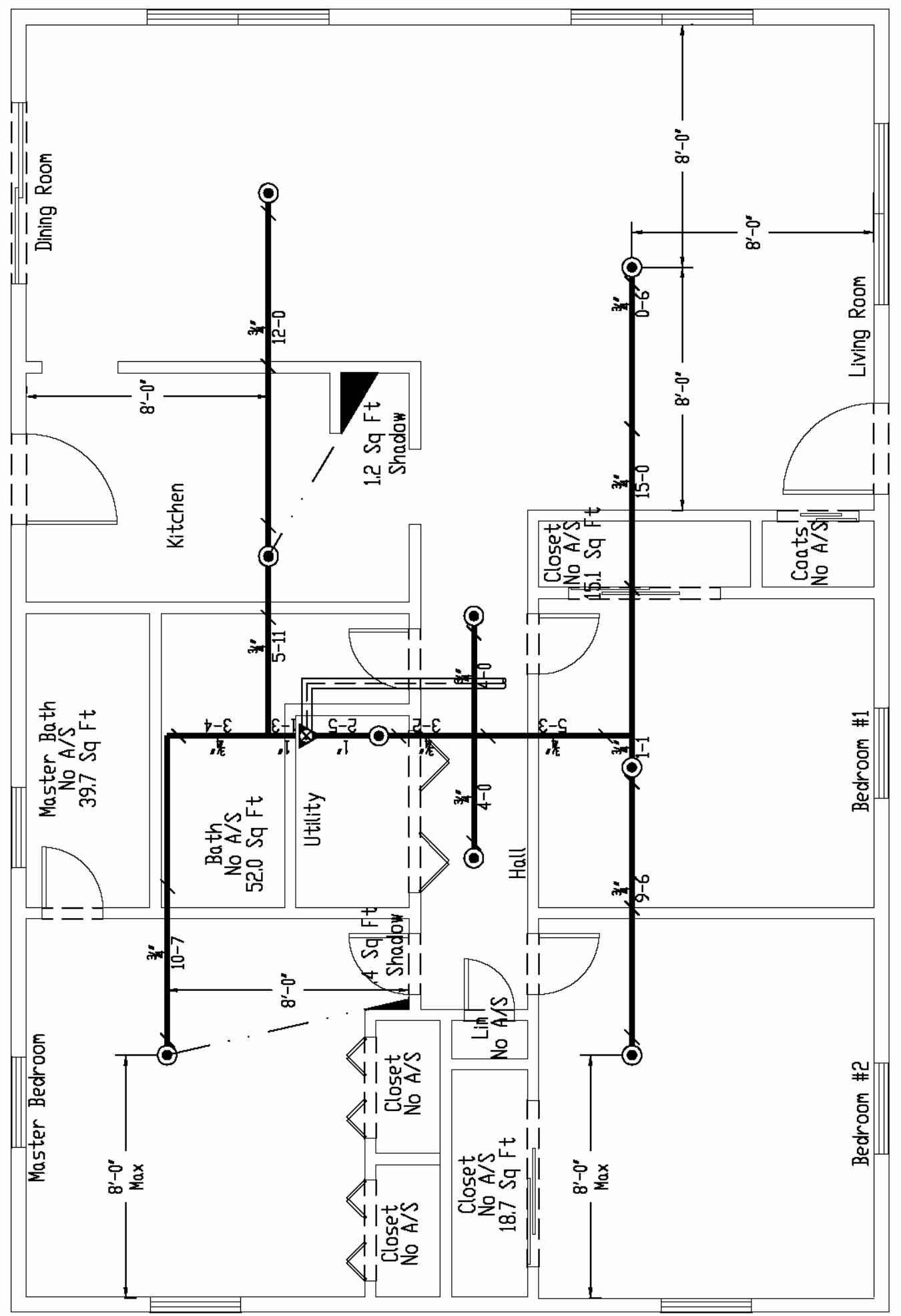




\section{Appendix C \\ Multipurpose Network Sprinkler Installation Plan}

The sprinkler system systems shown in this Appendix come from Alan Larson of Uponor Wirsbo. The floorplans are presented in customary units and are reproduced as they were received.

Figure C-1. Multipurpose Network Fire Sprinkler Installation in Colonial House Basement

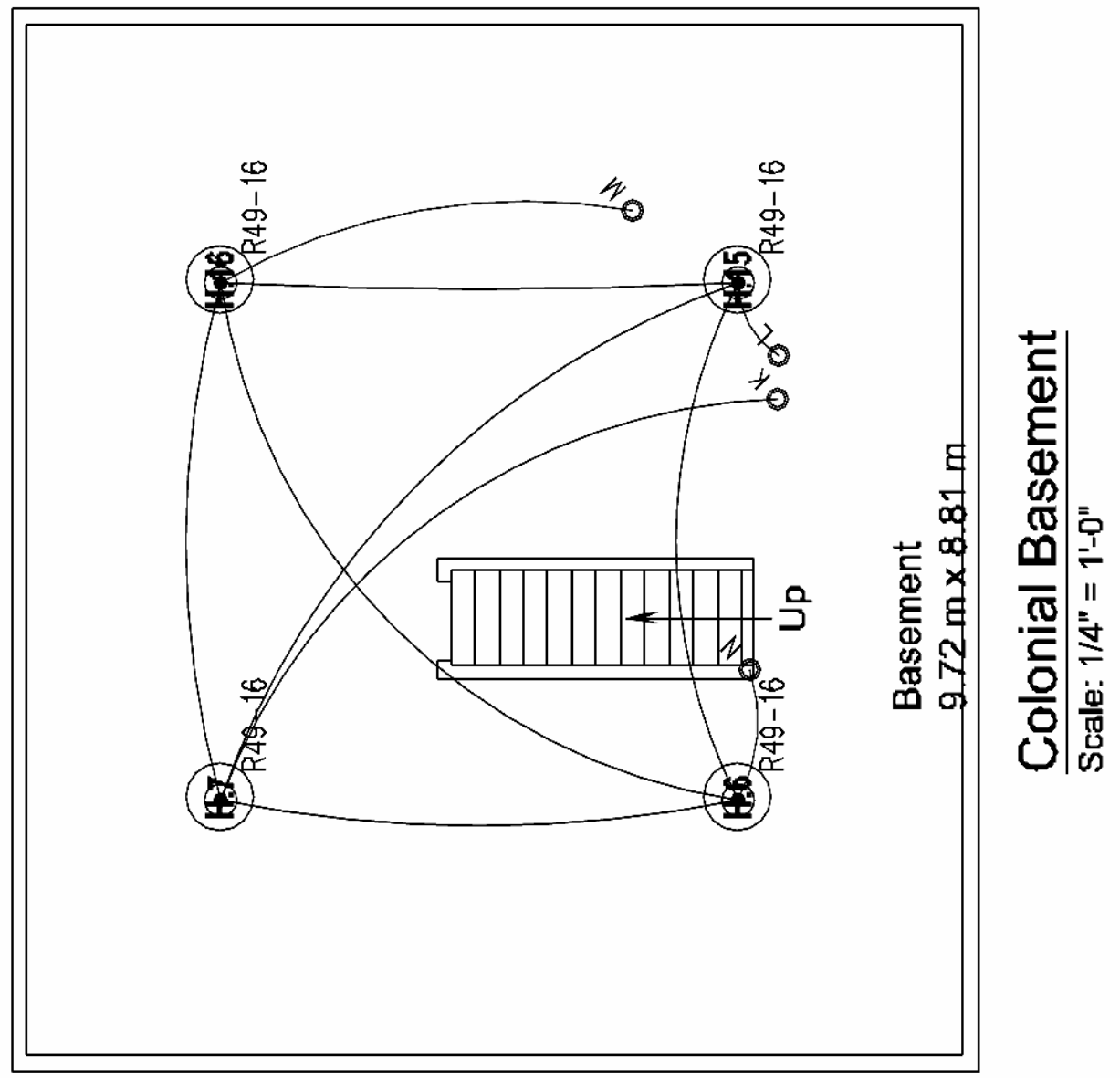


Figure C-2. Multipurpose Network Fire Sprinkler Installation in Colonial House 1st Floor

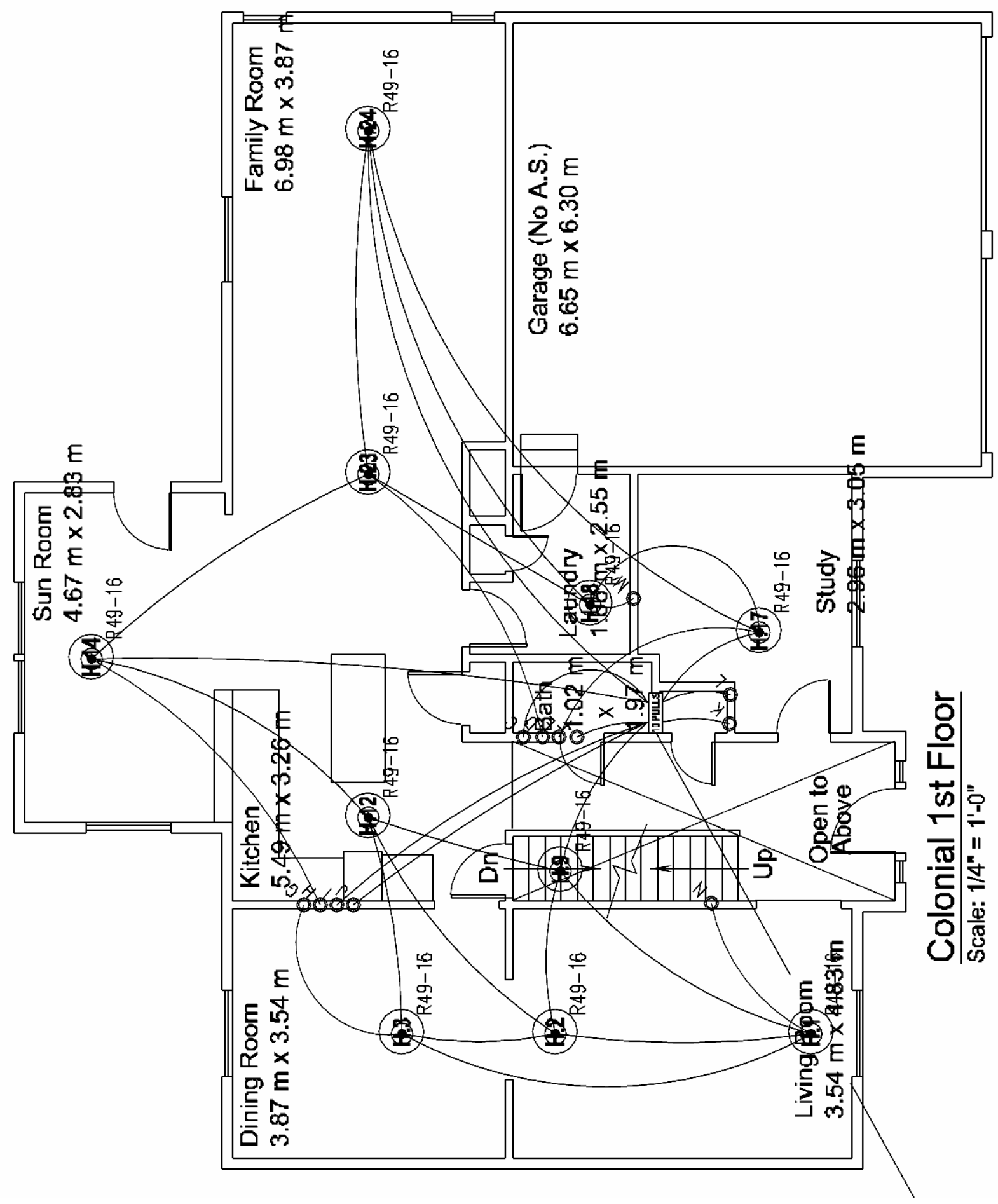


Figure C-3. Multipurpose Network Fire Sprinkler Installation in Colonial House 2nd Floor

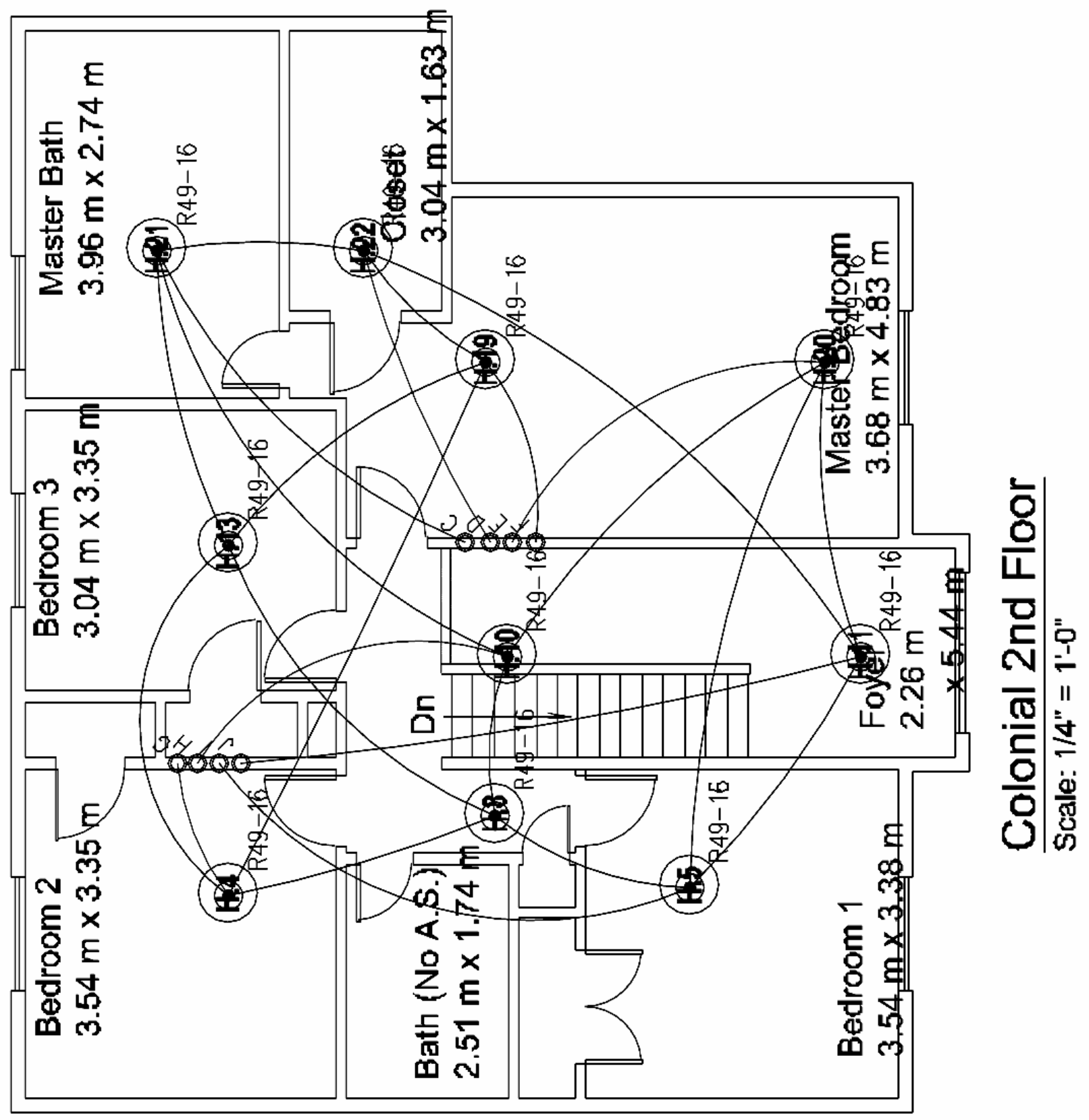


Figure C-4. Multipurpose Network Fire Sprinkler Installation in Townhouse
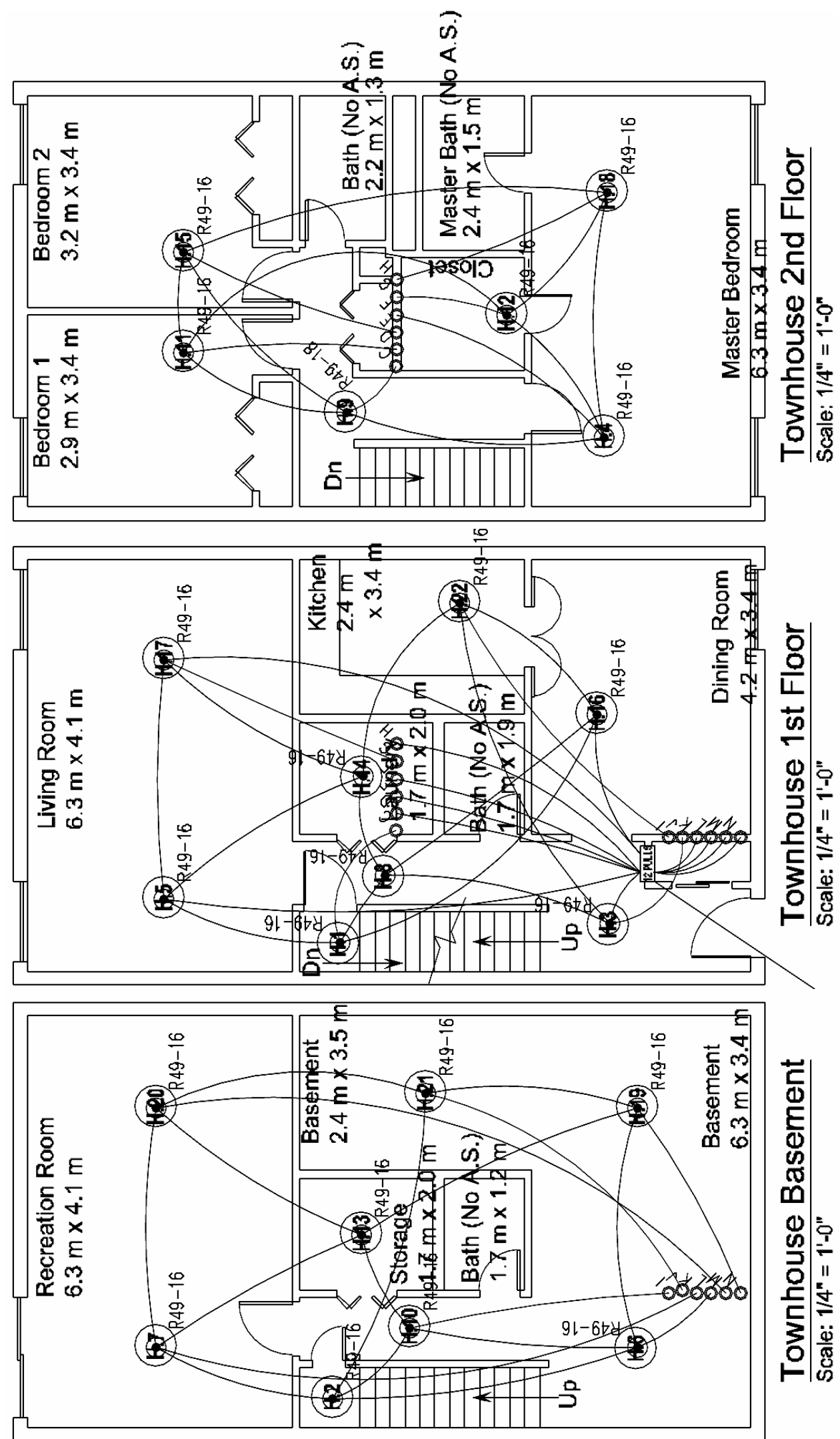
Figure C-5. Multipurpose Network Fire Sprinkler Installation in Ranch

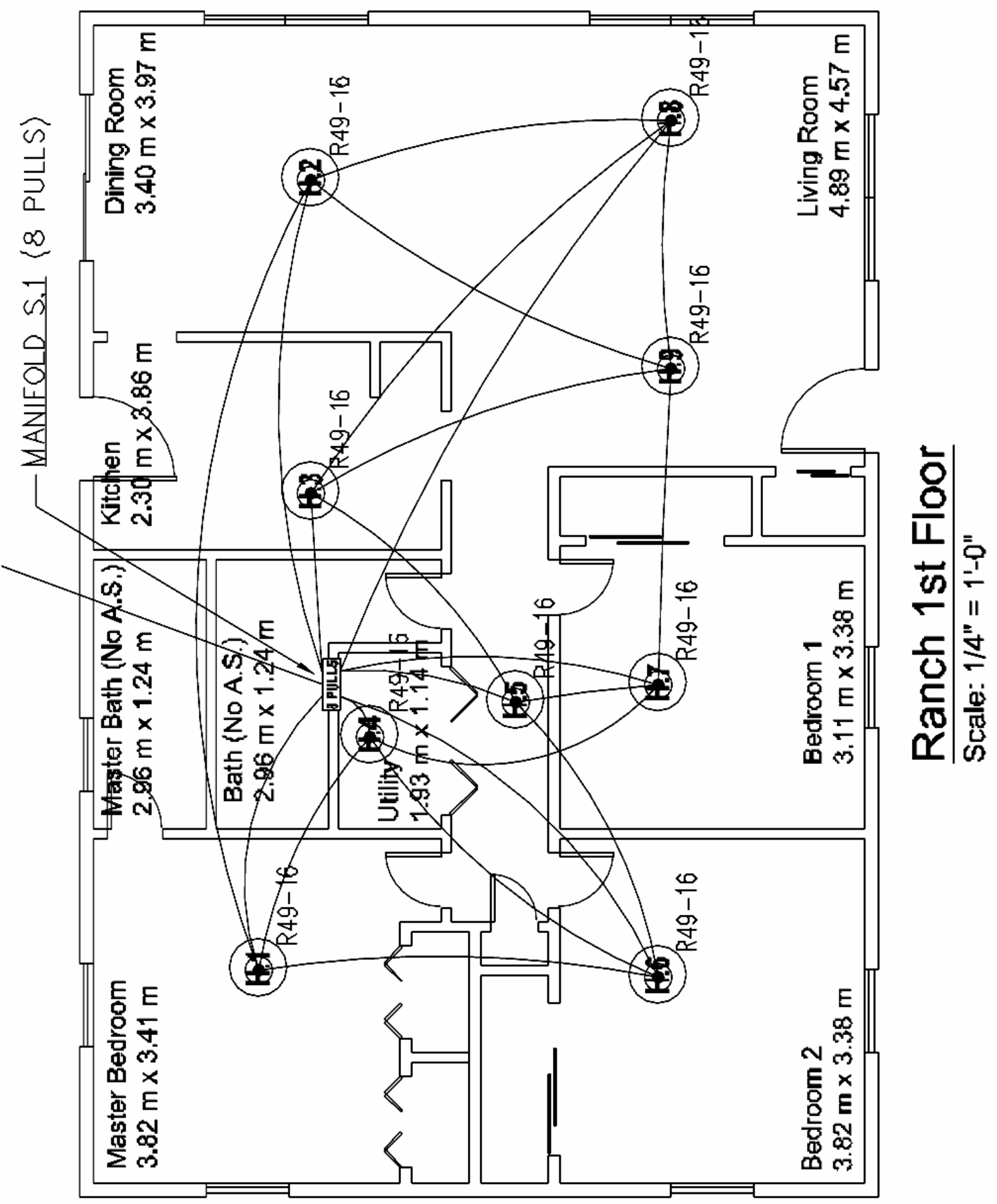

